\title{
National Set of MAES Indicators in Greece: Ecosystem Services and Management Implications
}

\author{
Ioannis P. Kokkoris ${ }^{1}{ }^{(\mathbb{O}}$, Georgios Mallinis ${ }^{2}{ }^{\mathbb{D}}$, Eleni S. Bekri ${ }^{3}$, Vassiliki Vlami ${ }^{4}$, \\ Stamatis Zogaris ${ }^{5}$, Irene Chrysafis ${ }^{2}\left(\mathbb{D}\right.$, Ioannis Mitsopoulos ${ }^{6}(\mathbb{D})$ and Panayotis Dimopoulos $1, *(\mathbb{B})$ \\ 1 Department of Biology, Laboratory of Botany, University of Patras, 26504 Patras, Greece; \\ ipkokkoris@upatras.gr \\ 2 Forest Remote Sensing and Geospatial Analysis Laboratory, Democritus University of Thrace, \\ 68200 Orestiada, Greece; gmallin@fmenr.duth.gr (G.M.); echrysaf@fmenr.duth.gr (I.C.) \\ 3 Department of Civil Engineering, Environmental Engineering Laboratory, University of Patras, 26504 Patras, \\ Greece; ebekri@upatras.gr \\ 4 Department of Environmental Engineering, University of Patras, 30100 Agrinion, Greece; \\ vasvlami@upatras.gr \\ 5 Hellenic Centre for Marine Research, Institute of Marine Biological Resources and Inland Waters, \\ 19013 Anavissos, Greece; zogaris@hcmr.gr \\ 6 Ministry of Environment \& Energy, Directorate of Biodiversity and Natural Environment Management, \\ 11526 Athens, Greece; i.mitsopoulos@prv.ypeka.gr \\ * Correspondence: pdimopoulos@upatras.gr; Tel.: +30-2610-996777
}

Received: 21 April 2020; Accepted: 21 May 2020; Published: 24 May 2020

\begin{abstract}
Research Highlights: The developed National Set of Indicators for the Mapping and Assessment of Ecosystems and their Services (MAES) implementation in Greece at the national level sets the official, national basis on which future studies will be conducted for MAES reporting for the achievement of targets within the National and the European Union (EU) biodiversity Strategy. Background and Objectives: Greece is currently developing and implementing a MAES nation-wide program based on the region's unique characteristics following the proposed methodologies by the European Commission, in the frame of the LIFE-IP 4 NATURA project (Integrated actions for the conservation and management of Natura 2000 sites, species, habitats and ecosystems in Greece). In this paper, we present the steps followed to compile standardized MAES indicators for Greece that include: (a) collection and review of the available MAES-related datasets, (b) shortcomings and limitations encountered and overcome, (c) identification of data gaps and (d) assumptions and framework setting. Correspondence to EU and National Strategies and Policies are also examined to provide an initial guidance for detailed thematic studies. Materials and Methods: We followed the requirements of the EU MAES framework for ecosystem services and ecosystem condition indicator selection. Ecosystem services reported under the selected indicators were assigned following the Common International Classification of Ecosystem Services. Spatial analysis techniques were applied to create relevant thematic maps. Results: A set of 40 MAES indicators was drafted, distributed in six general indicator groups, i.e., Biodiversity, Environmental quality, Food, material and energy, Forestry, Recreation and Water resources. The protocols for the development and implementation of an indicator were also drafted and adopted for future MAES studies in Greece, providing guidance for adaptive development and adding extra indicators when and where needed. Thematic maps representing ecosystem services (ES) bundles and ES hotspots were also created to identify areas of ES importance and simultaneously communicate the results at the national and regional levels.
\end{abstract}

Keywords: biodiversity; forestry; agriculture; recreation; water resources; natural resources management; adaptive monitoring; EU Green deal 


\section{Introduction}

Reaching the end of the European Union (EU) Biodiversity Strategy to 2020 [1], and seven years after the publication of the multi-cited master document for Mapping and Assessment of Ecosystem and their Services (MAES) in the EU [2], many EU Member States (MS) have developed methods (e.g., References [3-7]) and conducted case studies (e.g., References [8-10]) towards the implementation of Action 5 of Target 2 of the EU Biodiversity Strategy. From 2015 to 2018, the Horizon 2020 Coordination and Support Action, ESMERALDA (Enhancing ecoSysteM sERvices mApping for poLicy and Decision mAking), aimed at developing guidance and a flexible methodology to support the EU member states in the MAES implementation; more specifically, the main objective of ESMERALDA was to provide guidance for integrated mapping and assessment of ecosystem services (ES) that can be used for sustainable decision-making in policy, business, society, practice and science at EU, national and regional levels [11,12]. In parallel, a collection of papers by Burkhard and Maes [13] provides a comprehensive guidance for MAES implementation and in combination with the ever-updating MAES Explorer online [14,15], that supports ecosystem ES research and proposes systematic ways of assessment, mapping and reporting for biophysical, economic and social aspects of ES applications (as well as for their possible wider integration). Furthermore, an operational framework for integrated MAES, developed by Burkhard et al. [16], builds on the MAES common assessment framework [2] and re-organizes it on the basis of specific, practical steps needed to be followed to ensure an integrated result, at EU and national levels.

For graphical representation and mapping of ES, a tiered approach is proposed by Grêt-Regamey et al. [17], and updated in Burkhard and Maes [13] (Chapter 5.6.1), to support MAES studies at standardized scales of detail and data availability. Thus, it is obvious that the methods and tools available for operationalizing Action 5 of Target 2 of the EU Biodiversity across and within MS should be urgently elaborated. However, Albert et al. [18] highlighted that even with this guidance, national implementation of MAES requires the development of adapted sets of indicators that are most applicable to each respective context [19]. Due to this need, a debate on national indicators [20,21] and how they can be incorporated into policy, planning and management [22-25] is still ongoing.

Indicators are also fundamental elements for ES monetary valuation and Natural Capital (NC) accounting. Some have continued to argue that monetary valuation of ES and NC is inappropriate, and we should preserve and protect nature strictly 'for its own sake', for its 'intrinsic values' [26,27]. Costanza et al. [28] point out that this perspective is itself an implicit valuation: it is simply arguing that nature is more valuable than any possible alternative. While in many cases this may be true, society has made decisions implying that this is not always the case [29]. Through our historical and current interactions with the environment, in order to develop infrastructure and produce the goods necessary for contemporary life and well-being, we exploit ecosystems and impact NC. Thus, being more explicit about the value of ES and NC can help society make better decisions in the many cases in which trade-offs and complex conflicts exist [30,31].

Simultaneously, everything in applied science, management and decision-making is data-dependent, as well as in need of interpretation. Throughout the relevant literature (e.g., References [7,32-34]), it is highlighted that the crucial step for a successful MAES implementation is the identification, selection, elaboration and/or development of the appropriate indicators which capture in space and time ecosystems' performance regarding their condition and the multitude of services and benefits they provide. Selecting the appropriate indicators is identified as one of the fundamental steps of the operational framework as proposed by Burkhard et al. [16] and comprises a selection of (a) indicators for ecosystem condition (EC) and (b) indicators for ES.

The purpose of indicators is to measure and ascribe a value to the various dimensions $[35,36]$ of the complex ES concept [37]. Simultaneously, the indicator and indicandum (i.e., the phenomenon of interest reflected by the indicator) should be correlated with one another and the variance should be low [33]. It is clear that a common set of indicators cannot be applied across all the different ecosystem types; however, a standardized way of reporting ecosystem condition and ecosystem services at local, 
regional and national levels is important to support decision-making and strategic planning at MS and EU levels [2,38]. MAES indicators should have specific characteristics in order to support robust ES studies and should be applicable for policy-relevant interpretation, with the capacity to inform a broad array of policies related to the use, conservation and preservation of natural resources [38].

During the past five years, various studies guided by the MAES conceptual framework [2] have been conducted in Greece, providing information for different types of ecosystems and applying different methodologies and tools for mapping and assessing ES at local (e.g., Reference [39]), regional [40] and national levels [41-44]. In 2017, a group of scientists who believed in the importance of the MAES implementation (forming the Hellenic Ecosystem Partnership-HESP [45]) drafted the National Agenda for the MAES implementation in Greece [34] and set an Action Plan to 2020, including shortand mid-term objectives. Development and testing of a national set of indicators, by the end of 2020, is one of the mid-term objectives of the Agenda's Action Plan needed to be accomplished for further MAES implementation in Greece. The Life Integrated Project with the acronym "LIFE-IP 4 Natura" [46], led by the Hellenic Ministry of Environment and Energy, incorporates MAES implementation Actions at national, as well as at local (case-study) levels. These important developments towards standardizing MAES applications will also support NC accounting based on the System of Environmental Economic Accounting (SEEA)—Experimental Ecosystem Accounting [47].

This work aims to (a) collect and review all available data from national, regional and local authorities, which can be used to identify, assess and map ES at the national scale, (b) evaluate the potential usability of these data directly, after sorting and processing, or consider part of them as inappropriate for further use, and (c) identify ES data hot-spots and data-scarce areas in Greece. The final goal of the study is to provide a pre-defined National Set of Indicators for the MAES implementation at the national level. This set of Indicators will form the official, national basis on which future studies will be conducted for MAES, reporting towards supporting the targets of the National and the EU biodiversity Strategy.

\section{Materials and Methods}

\subsection{Preparatory Actions}

The initial overview of potential national indicators involved the following steps:

i. Identification of ecosystem types (terrestrial): using the Ecosystem type map of Europe [48], the Corine Land Cover dataset [49], the Natura 2000 Standard Data Forms and monitoring results [50,51] and spatial data for habitat types [52], and following the European Environment Agency (EEA) guidelines [53] and recent survey results [42,43], we have identified and classified the ecosystem types present in the Greek territory; a detailed ecosystem type mapping for Greece, i.e., MAES level 3 (sub-categories of MAES level 2 [2] ecosystem types in Greece) is an ongoing procedure of the LIFE-IP 4 NATURA project, summarized in Section 2.2.

ii. Literature review for ES indicators in Greece: we reviewed the provided list of primary and secondary ES indicators used for the site-level assessment of ES supply at mountainous Natura 2000 sites in Greece [42]. The overview on ecosystem condition indicators was based on the EU ecosystem condition assessment framework [38] and recent work for Greece [43].

iii. Exploration of data availability and quality: to identify and select possible indicators for (a) mapping and assessing ecosystem condition and ES, and (b) establishing a national set of indicators for future MAES studies, we revised and assessed (regarding their thematic detail and spatial scale) all available datasets for terrestrial ecosystems (based on the review by Dimopoulos et al. [34] and on datasets freely available by state authorities (Supplementary Table S1)), updated by the input of recent datasets and information from the relevant national and regional offices/authorities, after an official request by the Hellenic Ministry of Environment and Energy (leader of the LIFE-IP 4 Natura project). 
iv. Response to policy needs: using the guidance provided by Maes et al. [2,38] and in combination with the targets of (a) the EU Green Deal [54], (b) the Greek Biodiversity Strategy [55], (c) the Forest Strategy, (d) the Regional Policy, (e) the Agricultural Policy, (f) the Climate Policy and (g) the Water Policy, each indicator was evaluated and assigned with a " 1 " (yes) or " 0 " (no) mark regarding its direct relation with the above-mentioned strategies and policies.

v. Supporting valuation and NC assessments: using a simple scaling method, experts from the LIFE-IP 4 NATURA consortium rated each indicator's dataset for its ability to support valuation and NC studies (i.e., 0-not relevant, 1-very low, 2-low, 3-medium, 4-high, 5-ready for use). This allowed the co-authors to decide on final indicators and to explore the uncertainty, data availability and applicability.

\subsection{Drafting the National Set of Indicators}

The selection of indicators to be drafted for the National Set was based on the requirements of the MAES indicator framework for ecosystem condition [38] (Table 1). These are considered as appropriate also for ES indicators, since ES are directly dependent on the condition of ecosystems (e.g., References [56-58]). Each indicator has been assessed for its compliance with the predefined requirements.

Table 1. Requirements for the Mapping and Assessment of Ecosystem and their Services (MAES) indicator framework on ecosystem condition assessment [38]. Numbers in column "Code" are used to assign the requirements with each one of the assessed indicators for the present study.

\begin{tabular}{|c|c|c|}
\hline Requirements & Description & Code \\
\hline Scientifically sound & $\begin{array}{l}\text { Indicators should be based on the best available } \\
\text { knowledge while giving a good representation of the } \\
\text { ecosystem characteristics addressed. }\end{array}$ & 1 \\
\hline Supporting environmental legislation & $\begin{array}{l}\text { Indicators should support the implementation of } \\
\text { environmental legislation in the European Union (EU). }\end{array}$ & 2 \\
\hline Policy-relevant & $\begin{array}{l}\text { Indicators should be policy-relevant: they have multiple } \\
\text { policy uses and can support a policy narrative which } \\
\text { links pressures, ecosystem condition, ecosystem services } \\
\text { and policy objectives. }\end{array}$ & 3 \\
\hline $\begin{array}{l}\text { Include habitat and species } \\
\text { conservation status }\end{array}$ & $\begin{array}{l}\text { The conservation status of habitats and species (and in } \\
\text { particular the parameters "area" and "structure and } \\
\text { function") reported under Art.17 of the EU Habitats } \\
\text { Directive should constitute a major indicator for } \\
\text { assessing ecosystem condition. }\end{array}$ & 4 \\
\hline Include soil-related information & $\begin{array}{l}\text { Terrestrial ecosystems are not in good condition if their } \\
\text { soils are not in good condition. Specific indicators which } \\
\text { assess the condition of soils should therefore be included. }\end{array}$ & 5 \\
\hline Applicable for natural capital accounts & $\begin{array}{l}\text { The indicator framework should support the } \\
\text { development and testing of ecosystem extent and } \\
\text { condition accounts. }\end{array}$ & 6 \\
\hline Spatially explicit & $\begin{array}{l}\text { Ecosystem condition is not equal across space. Different } \\
\text { spatial gradients of pressures and differences in the } \\
\text { response of ecosystems to pressures result in spatial } \\
\text { variance of ecosystem condition, which needs to be } \\
\text { acknowledged in the indicator selection. }\end{array}$ & 7 \\
\hline Baseline & $\begin{array}{l}\text { Indicators should be measurable relative to a baseline } \\
\text { year (e.g., 2010). }\end{array}$ & 8 \\
\hline Sensitive to change & Indicators should be able to detect change over time. & 9 \\
\hline
\end{tabular}

The Common International Classification of Ecosystem Services (CICES ver. 5.1) [59] was used to assign ES reported under the selected indicators, with the international and EU practice of reporting ES. The selected indicators are also assigned to the corresponding categories of ES indicators, proposed in the second MAES report [32], followed by the designation of the relevant terrestrial MAES level 2 ecosystem type (i.e., Urban, Cropland, Grassland, Woodland and forest, Heathland and shrub, Sparsely vegetated land, Wetlands, Rivers and Lakes). 
Moreover, each indicator is selected and tagged on the basis of its potential for application at the different tier assessments, i.e., tier 1 approach relies on widely available data and can be used to provide a rough overview of ES, tier 2 approach includes more specific information for the case study area, while tier 3 is the most data- and resource-demanding approach and is appropriate for large-scale and highly detailed assessments [13,17]. The steps followed to draft the final set of MAES indicators are presented in Figure 1.
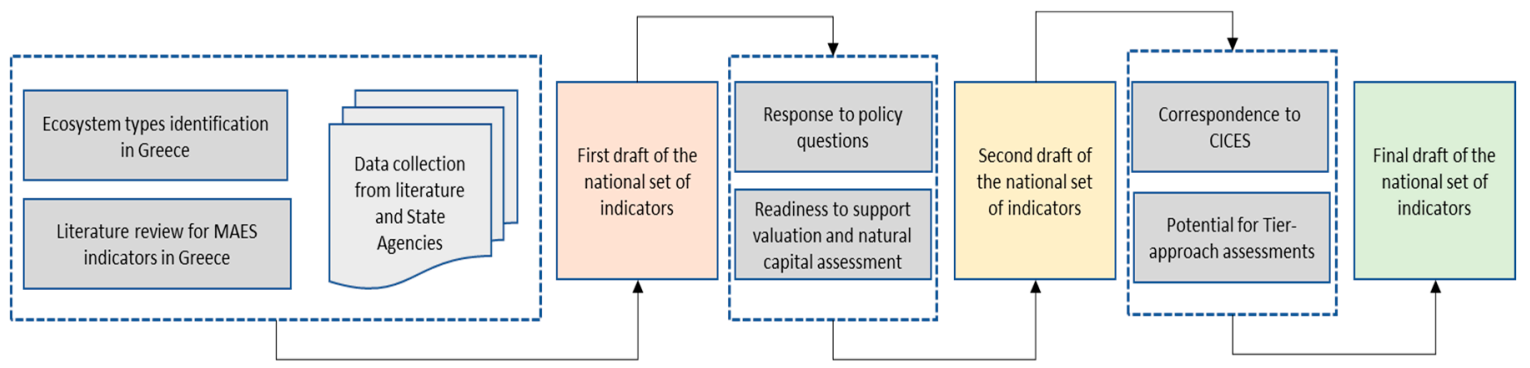

Figure 1. Steps followed for drafting the National Set of MAES Indicators. CICES: Common International Classification of Ecosystem Services.

Analysis of indicator-related data availability in space, time and scale has also been conducted and represented in thematic maps, identifying areas with data gaps, as well as areas where MAES implementation can be operationalized.

The above-mentioned procedure is the core part of the MAES implementation in Greece under the LIFE-IP 4 NATURA project and the relevant procedure flowchart is presented in Figure 2.

\section{Development and Implementation of Indicators' Protocols}

Following Kettunen et al. [60], Ferrari and Geneletti [61] and Nedkov et al. [62], we propose structured protocols for (a) the development and (b) the implementation of MAES indicators in Greece. This is to provide guidance on how to develop and implement indicators at various scales in future MAES studies. More precisely:

a. Development of the indicator protocol fields: (i) Indicator name (name of the index for national use), (ii) Definition (summary definition of the index), (iii) Description (summary description of the index), (iv) Application (for ES and/or EC assessments), (v) Use and interpretation (local, regional, national), (vi) Measurement units (e.g., $\mathrm{m}^{3} / \mathrm{ha}$ ), (vii) Data source (e.g., Ministry of Environment and Energy), (viii) Calculation method (detailed description of the method used to calculate the index).

b. Implementation of the indicator protocol fields: (i) Indicator name (name of the index for national use), (ii) Responsible, coordinating authority for the implementation (authority/organization, etc., and person responsible for indicator calculation and communication), (iii) Use and interpretation (includes: key questions to which the indicator responds, (iv) Users of the indicator, (v) Appropriate scale for the implementation, (vi) Potential for aggregation (interpretation of increasing or decreasing trends, possible causes for these trends), (vii) Impact of indicator alterations/change to management, (viii) Measurement unit, (ix) Data source, (x) Calculation method, (xi) Presentation of the index (maps, graphs, tables, etc., appropriate for communication purposes), (xii) Limitations of index utility and accuracy, (xiii) Update/revision of the index (frequency and procedure), (xiv) Relative indicators (report relevant indices if available), (xv) Additional information and comments (free text).

The proposed development protocol was used for the indicators of the present study. 


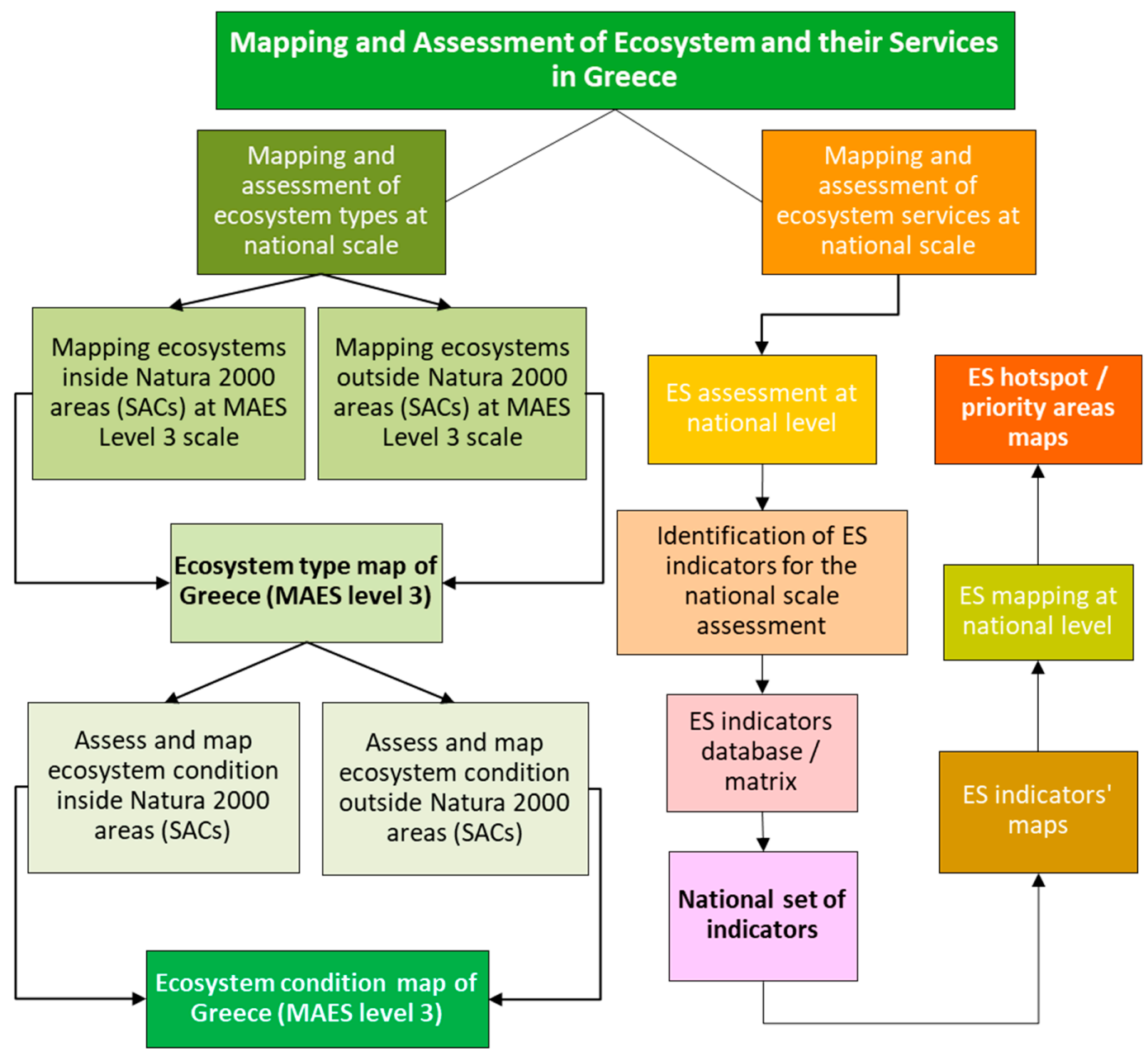

Figure 2. Flowchart for the MAES implementation in Greece, during the LIFE-IP 4 NATURA project (Integrated actions for the conservation and management of Natura 2000 sites, species, habitats and ecosystems in Greece). SAC: Special Areas of Conservation, ES: ecosystem services.

\subsection{Thematic Maps}

\subsubsection{ES Indicators Bundles}

To pinpoint ES hotspot areas, as well as areas where multiple ES are likely to be supplied simultaneously (ES bundles) in space and/or time, thematic maps have been prepared, by depicting indicator-related data overlaps; by this, areas of ES importance (high to low) are identified and the relevant priority MAES maps (priority areas maps) have been drafted. To identify areas where multiple ES are simultaneously supplied (or potentially supplied) in spatial and/or temporal terms, we used spatial analysis, and layer-overlay techniques, at the $10 \times 10 \mathrm{~km}$ EEA reference grid for Greece [63], using Geographic Information Systems; thus, we highlighted areas where ES bundles are present and further study is needed at a more detailed level (i.e., regional and local levels). This methodology is based on the following assumptions: (a) each indicator layer was considered as of equal importance and its presence in each grid cell is assigned to a binary value, i.e., 0 : not present, 1 : present, in cell, (b) summing all values from the overlaying layers in each cell, represents each cell's importance for ES (higher values at cell represent higher importance and vice versa), (c) the available, spatial-referenced datasets were used for: (i) forest-management studies, (ii) wind-energy stations, (iii) hydroelectric-energy stations, (iv) solar-energy stations, (v) national forests, (vi) Natura 2000 areas and/or wildlife refuges, (vii) "blue flag" beaches, (viii) thermal springs, (ix) inland boating and rafting, (x) mountain shelters, (xi) cropland area and (xii) water resources, (d) these datasets were used as 
single or combined categorical variables, by recording their presence in each $10 \times 10$ EEA reference grid cell of Greece. By this, a matrix calculating the presence of the various datasets per grid cell has been created. The categorization of the total sum of the various datasets' availability in each grid cell, using GIS software, resulted in a thematic ES bundles national map, based on MAES-related available datasets for Greece. To support MAES knowledge at the administrative, regional-management level, the representativity of ES bundles at the regional (NUTS 2) level has also been prepared and presented using the analytics and visualization Tableau online platform (ver. 2020.1) [64] for the six general groups (i.e., Biodiversity, Environmental quality, Food, material and energy, Forestry, Recreation, Water resources) of the proposed set of indicators. The area of each region is also integrated in the analysis in order to encapsulate the relative importance of each region regarding the potential ES provision.

\subsubsection{ES Hotspots}

Using the $10 \times 10 \mathrm{~km}$ EEA reference grid, ES hotspots are also depicted in thematic maps, representing areas at which a particular ecosystem service is provided (potential supply) in large proportions [65]. Large proportions refer to a high spatial density and extent of ES indicator spatial data.

\subsubsection{Compliance with the MAES Indicator Framework}

Maps of compliancy with the indicators' requirements [38] and as presented in Table 1 are also drafted using the total number of requirements simultaneously provided at each $10 \times 10 \mathrm{~km}$ EEA reference grid cell.

\subsubsection{Data Gaps}

Since this exercise depicts current knowledge and is based on the best available datasets, data gaps must sometimes be overlooked to expedite applications. However, defining data gaps is crucial for concrete management and decision-making; thus, data-gap maps have also been drafted on the basis of the $10 \times 10 \mathrm{~km}$ EEA reference grid. The overlay method, as described above, was also used to pinpoint the data-scarce areas by creating the relevant readiness maps for the MAES implementation in Greece, regarding (a) the indicator groups and (b) indicator groups' cumulative importance, in each region of Greece (NUTS 2).

\subsubsection{Relevance to Policies}

Indicator relevance with national strategies and polices (i.e., biodiversity strategy, forest strategy, regional policy, agricultural policy, climate policy and water policy) and with the EU "Green deal" set of transformative policies (i.e., clean energy, sustainable industry, building and renovating, sustainable mobility, biodiversity, "from farm to fork", eliminating pollution) is also considered. A thematic representation of the indicators relevance (as approached in Section 2.1, iv) was drafted to initially assess the indicators' potential use for implementing and evaluating various policies, across the Greek terrestrial territory.

\section{Results}

\subsection{Classification Scheme of Terrestrial Ecosystem Types in Greece}

The results of the drafted classification scheme for terrestrial ecosystem types in Greece proposes 28 MAES level 3 ecosystem types, included in eight MAES level 2 categories. More precisely, 110 habitat types are distributed along 19 MAES level 3 ecosystem types:

- Grassland: 13 habitat types in Natural grasslands.

- Woodland and forest: (i) seven habitat types in Temperate deciduous forests, (ii) seven habitat types in Mediterranean deciduous forests, (iii) five habitat types in Floodplain forests (Riparian forest/Fluvial forest), (iv) six habitat types in Temperate mountainous coniferous forests, (v) four 
habitat types in Mediterranean coniferous forests, (vi) four habitat types in Mediterranean sclerophyllous forests and (vii) one habitat type in Mixed Forest.

- Heathland and shrub: (i) five habitat types in Moors and heathland and (ii) 10 habitat types in Sclerophyllous vegetation.

- Sparsely vegetated land: (i) 11 habitat types in Sparsely vegetated areas and (ii) eight habitat types in Beaches, dunes, sands.

- Wetlands: (i) three habitat types in Inland freshwater marshes, (ii) six habitat types in Inland saline marshes, (iii) four habitat types in Peat bogs and (iv) eight habitat types in Marine wetlands.

- $\quad$ Rivers and lakes: (i) five habitat types in Rivers and (ii) four habitat types in Lakes.

A detailed crosswalk among habitat types and ecosystem type levels is presented in Table 2. This typology will be used for the national scale MAES level 3 ecosystem type mapping and will provide a base-line map for the MAES implementation in Greece, under the LIFE-IP 4 Natura project.

\subsection{Indicators for ES and EC Assessments}

\subsubsection{Selection of Indicators}

A set of 40 indicators (Table 3) which comprises six groups of indicators, i.e., (i) Biodiversity, (ii) Environmental quality, (iii) Food, material and energy, (iv) Forestry, (v) Recreation and (vi) Water resources, has been drafted for Greece. The selected indicators cover all the three CICES sections as follows:

- Provisioning services: 15 indicators, corresponding to 10 CICES codes.

- Regulating and maintenance services: 18 indicators, corresponding to 22 CICES codes.

- Cultural services: 6 indicators, corresponding to 3 CICES codes.

Most of the indicators can be used for ES assessments, as well as for EC assessments; more precisely, 33 indicators comply for ES assessments (nine of them are exclusively applicable for ES assessments), while 30 indicators are suitable for EC assessments (four of them are exclusively applicable for EC assessments) (Table 3).

Figure 3 and Supplementary Table S1, present the correlations among ecosystem types and the proposed national set of MAES indicators. Regarding their utility per MAES level 2 ecosystem type, the proposed indicators are distributed as follows:

- Urban: 9 indicators (two from Biodiversity, three from Environmental quality, two from Food, material and energy and two from Recreation).

- Cropland: 11 indicators (four from Biodiversity, three from Environmental quality, two from Food, material and energy and two from Recreation).

- Grassland: 11 indicators (three from Biodiversity, three from Environmental quality, two from Food, material and energy, one from Forestry and two from Recreation).

- Woodland and forest: 20 indicators (three from Biodiversity, eight from Environmental quality, one from Food, material and energy, five from forestry and three from Recreation).

- Heathland and shrub: 17 indicators (four from Biodiversity, six from Environmental quality, three from Food, material and energy, two from forestry and two from Recreation).

- Sparsely vegetated land: 11 indicators (three from Biodiversity, three from Environmental quality, two from Food, material and energy, five from forestry and three from Recreation).

- Wetlands: 8 indicators (three from Biodiversity, three from Environmental quality and two from Recreation).

- Rivers and lakes: 15 indicators (three from Biodiversity, one from Environmental quality, one from Food, material and energy, three from Recreation and seven from Water resources).

- Marine inlets and transitional waters: 7 indicators (two from Biodiversity, three from Environmental quality and two from recreation). 
Table 2. Classification of the ecosystem types (MAES level 3), for mapping and assessment in terrestrial areas of Greece.

\begin{tabular}{|c|c|c|c|}
\hline $\begin{array}{l}\text { MAES Ecosystem } \\
\text { Category (Level 1) }\end{array}$ & $\begin{array}{l}\text { Ecosystem Type for } \\
\text { Mapping and } \\
\text { Assessment (Level 2) }\end{array}$ & $\begin{array}{l}\text { Ecosystem Type for Mapping and } \\
\text { Assessment in Greece (Level 3) }\end{array}$ & Habitat Type Codes \\
\hline \multirow{28}{*}{ Terrestrial } & \multirow{3}{*}{ Urban } & $\begin{array}{l}\text { Dense to medium dense Urban Fabric (IM.D. } \\
30 \%-100 \%+\text { industrial, commercial, public, } \\
\text { military and private units) }\end{array}$ & - \\
\hline & & Low-density Urban Fabric (IM.D. $0 \%-30 \%$ ) & - \\
\hline & & Other/Transport & - \\
\hline & \multirow{3}{*}{ Cropland } & Arable land & - \\
\hline & & Permanent crops & - \\
\hline & & Heterogeneous agricultural areas & - \\
\hline & \multirow{3}{*}{ Grassland } & Managed grassland & - \\
\hline & & $\begin{array}{l}\text { Natural grasslands prevailingly without trees } \\
\text { and scrubs (T.C.D. }<30 \% \text { ) }\end{array}$ & $\begin{array}{l}6110 *, 6170,6220 *, 6230 * \\
6290,62 \mathrm{~A} 0,62 \mathrm{D} 0,6420,6430, \\
6510,651 \mathrm{~A}, \mathrm{G} 628, \mathrm{G} 645\end{array}$ \\
\hline & & $\begin{array}{l}\text { Natural grasslands with trees and scrubs } \\
\text { (T.C.D. }>30 \% \text { ) }\end{array}$ & $\begin{array}{l}6110 *, 6170,6220 *, 6230 * \\
6290,62 \mathrm{~A} 0,62 \mathrm{D} 0,6420,6430, \\
6510,651 \mathrm{~A}, \mathrm{G} 628, \mathrm{G} 645\end{array}$ \\
\hline & \multirow{7}{*}{ Woodland and forest } & Temperate deciduous forests & $\begin{array}{l}\text { 9110, 9130, 9140, 9150, 9180, } \\
\text { G91K, G91L }\end{array}$ \\
\hline & & Mediterranean deciduous forests & $\begin{array}{c}\text { 91M0, 9280, 9250, 9310, 9350, } \\
9260,925 \mathrm{~A}\end{array}$ \\
\hline & & $\begin{array}{l}\text { Floodplain forests (Riparian forest/Fluvial } \\
\text { forest) }\end{array}$ & $\begin{array}{l}\text { 92A0, 92C0, 92D0, 91E0* } \\
91 \mathrm{~F} 0\end{array}$ \\
\hline & & Temperate mountainous coniferous forests & $\begin{array}{c}9530 *, 951 \mathrm{~B}, 91 \mathrm{BA}, 91 \mathrm{CA}, \\
9410,95 \mathrm{~A} 0\end{array}$ \\
\hline & & Mediterranean coniferous forests & $2270,9540,9560,9290$ \\
\hline & & Mediterranean sclerophyllous forests & $9340,934 \mathrm{~A}, 9320,9370$ \\
\hline & & Mixed Forest & 9270 \\
\hline & \multirow{2}{*}{ Heathland and shrub } & Moors and heathland & $4060,4090,5360,5420,5430$ \\
\hline & & Sclerophyllous vegetation & $\begin{array}{l}2250 *, 5110,5150,5160,5210, \\
5230,5310,5330,5340,5350\end{array}$ \\
\hline & \multirow{6}{*}{ Sparsely vegetated land } & Sparsely vegetated areas & $\begin{array}{c}8130,8140,8210,8220,8230 \\
8310,8320,8330,2240,2260, \\
9620\end{array}$ \\
\hline & & Beaches, dunes, sands & $\begin{array}{l}1210,1240,1410,2110,2120, \\
2220,2230,2210\end{array}$ \\
\hline & & Bare rock & - \\
\hline & & Burnt areas & - \\
\hline & & Glaciers and perpetual snow & - \\
\hline & & Mines, dumps, land without current use & - \\
\hline & \multirow{4}{*}{ Wetlands } & Inland freshwater marshes & 72A0, 72B0, 2190 \\
\hline & & Inland saline marshes & $\begin{array}{c}1310,1410,1420,1430,1510, \\
1440\end{array}$ \\
\hline & & Peat bogs & $7140,7210,7220,7230$ \\
\hline & & Marine wetlands & $\begin{array}{c}\text { 1110, } 1120,1130,1150,1160 \\
1170,1180,1310\end{array}$ \\
\hline \multirow{2}{*}{ Freshwater } & \multirow{2}{*}{ Rivers and lakes } & Rivers & $3240,3250,3260,3280,3290$ \\
\hline & & Lakes & $3130,3140,3150,3170$ * \\
\hline
\end{tabular}

IM.D.: Impervious Degree, T.C.D.: Total Canopy Density, ${ }^{*}$ : Habitat types of conservation priority in Europe. 
Table 3. National Set of indicators for the MAES implementation in Greece, their correspondence with the Common International Classification of Ecosystem Services (CICES) sections and codes and their utility for ES and/or EC assessments.

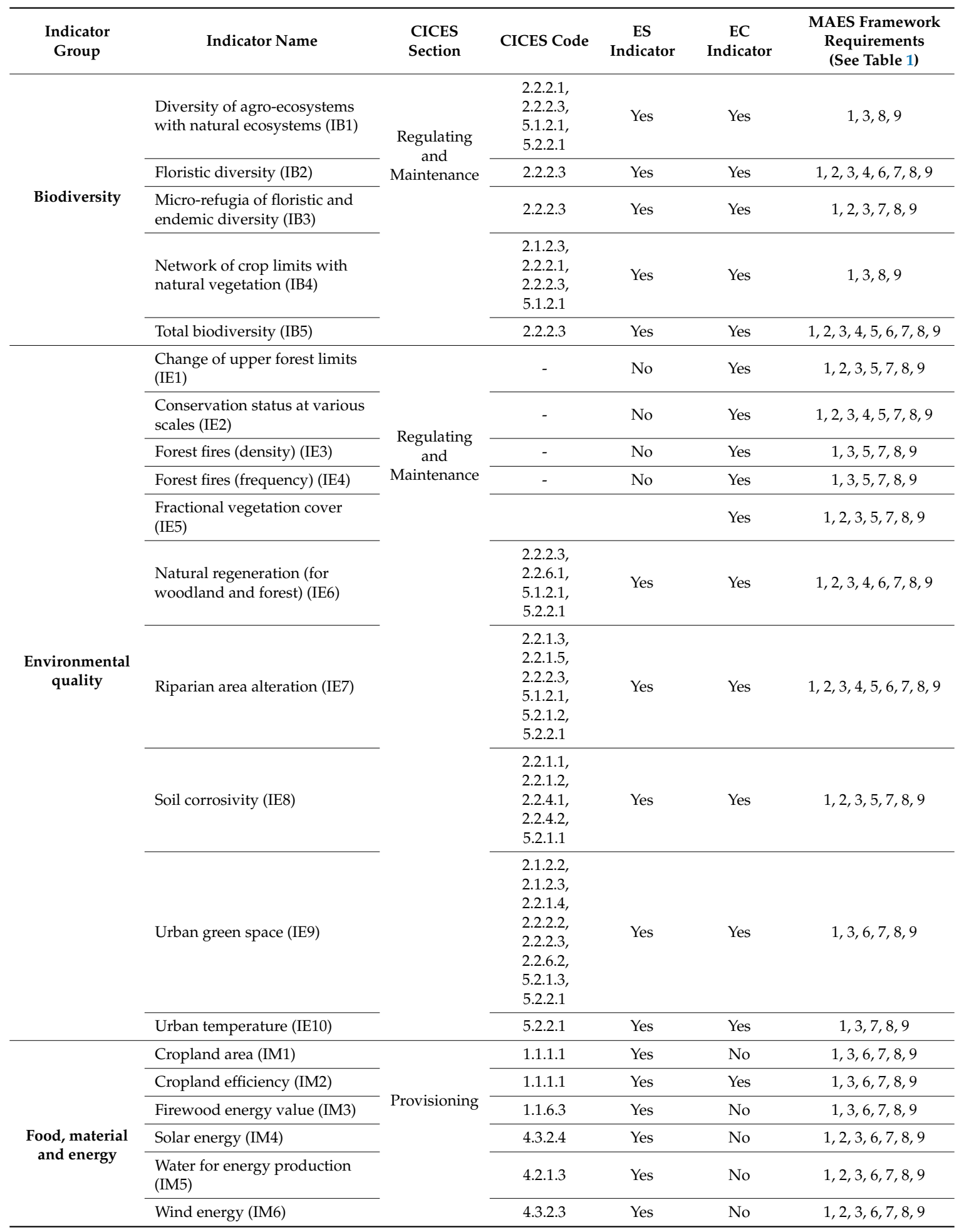


Table 3. Cont.

\begin{tabular}{|c|c|c|c|c|c|c|}
\hline $\begin{array}{l}\text { Indicator } \\
\text { Group }\end{array}$ & Indicator Name & $\begin{array}{l}\text { CICES } \\
\text { Section }\end{array}$ & CICES Code & $\begin{array}{c}\text { ES } \\
\text { Indicator }\end{array}$ & $\begin{array}{c}\mathrm{EC} \\
\text { Indicator }\end{array}$ & $\begin{array}{l}\text { MAES Framework } \\
\text { Requirements } \\
\text { (See Table 1) }\end{array}$ \\
\hline \multirow{4}{*}{ Forestry } & Available firewood (IF1) & \multirow{4}{*}{ Provisioning } & 1.1.5.3 & Yes & Yes & $1,3,6,7,8,9$ \\
\hline & Pasture productivity (IF2) & & 1.1.5.1 & Yes & Yes & $1,3,6,7,8,9$ \\
\hline & Standing volume (IF3) & & 1.1.5.2 & Yes & Yes & $1,3,6,7,8,9$ \\
\hline & Wood harvest (IF6) & & 1.1.5.2 & Yes & Yes & $1,3,6,7,8,9$ \\
\hline \multirow{3}{*}{ Recreation } & National forests (IR1) & \multirow{3}{*}{ Cultural } & 6.2.2.1 & Yes & No & $1,2,3,6,7,8,9$ \\
\hline & $\begin{array}{l}\text { Inland waters rafting and } \\
\text { boating (IR2) }\end{array}$ & & 6.1.1.1 & Yes & No & $1,3,6,7,8$ \\
\hline & Visitors' preferences (IR6) & & 6.1.2.1 & Yes & Yes & $1,3,6,7,8$ \\
\hline \multirow{5}{*}{ Water resources } & $\begin{array}{l}\text { Ability to satisfy demand by } \\
\text { water use (IW1) }\end{array}$ & Provisioning & $\begin{array}{l}4.2 .1 .1 \\
4.2 \cdot 1.2\end{array}$ & Yes & Yes & $1,3,6,7,8$ \\
\hline & $\begin{array}{l}\text { Chemical condition of surface } \\
\text { water (for rivers and lakes) } \\
\text { (IW2) }\end{array}$ & $\begin{array}{l}\text { Regulating } \\
\text { and } \\
\text { Maintenance }\end{array}$ & $\begin{array}{l}2.2 .5 .1 \\
5.2 .2 .1\end{array}$ & Yes & Yes & $1,2,3,4,5,6,7,8,9$ \\
\hline & $\begin{array}{l}\text { Chemical condition of } \\
\text { underground water (IW3) }\end{array}$ & $\begin{array}{l}\text { Regulating } \\
\text { and } \\
\text { Maintenance }\end{array}$ & $\begin{array}{l}2.2 .5 .1 \\
5.2 .2 .1\end{array}$ & Yes & Yes & $1,2,3,4,5,6,7,8,9$ \\
\hline & Demand (total use) (IW4) & Provisioning & $\begin{array}{l}4.2 .1 .1 \\
4.2 .1 .2\end{array}$ & Yes & Yes & $1,3,6,7,8$ \\
\hline & $\begin{array}{l}\text { Water exploitation index-WEI } \\
\text { (IW7) }\end{array}$ & Provisioning & 4.2.2.4_W3 & Yes & Yes & $1,3,6,7,8$ \\
\hline
\end{tabular}

W1, W2, W3: working code for Greece (following the guidelines of the CICES regarding the creation of additional working codes).

\subsubsection{Data Quality and Suitability for Tiers}

Due to the methodology applied for the indicators' selection, most indicators are suitable for tier 1 and tier 2 mapping (except for the indicators "Conservation status at various scales", "Demand (total use)" of water, "Water exploitation index-WEI" and "Ability to satisfy demand by water use", which are applicable for national-scale mapping). This is because spatial information for each indicator is provided at the level of the management unit (e.g., available stock for each managed forest class, cultivation and product type by each land parcel, kilometers of trails with georeferenced trace, etc.). However, most of the indicators cannot be used for tier 3 ES assessments and further elaboration (e.g., modelling) or field work is needed (e.g., for biodiversity assessment at the local level). Supplementary Table S1 (a) provides in detail all the available information for the National Set of Indicators and highlights their readiness for each tier-oriented study by a characteristic color coding, (b) simultaneously summarizes all the available knowledge from official designated sources of information and (c) is drafted as a baseline for the future steps of the MAES implementation in Greece. 


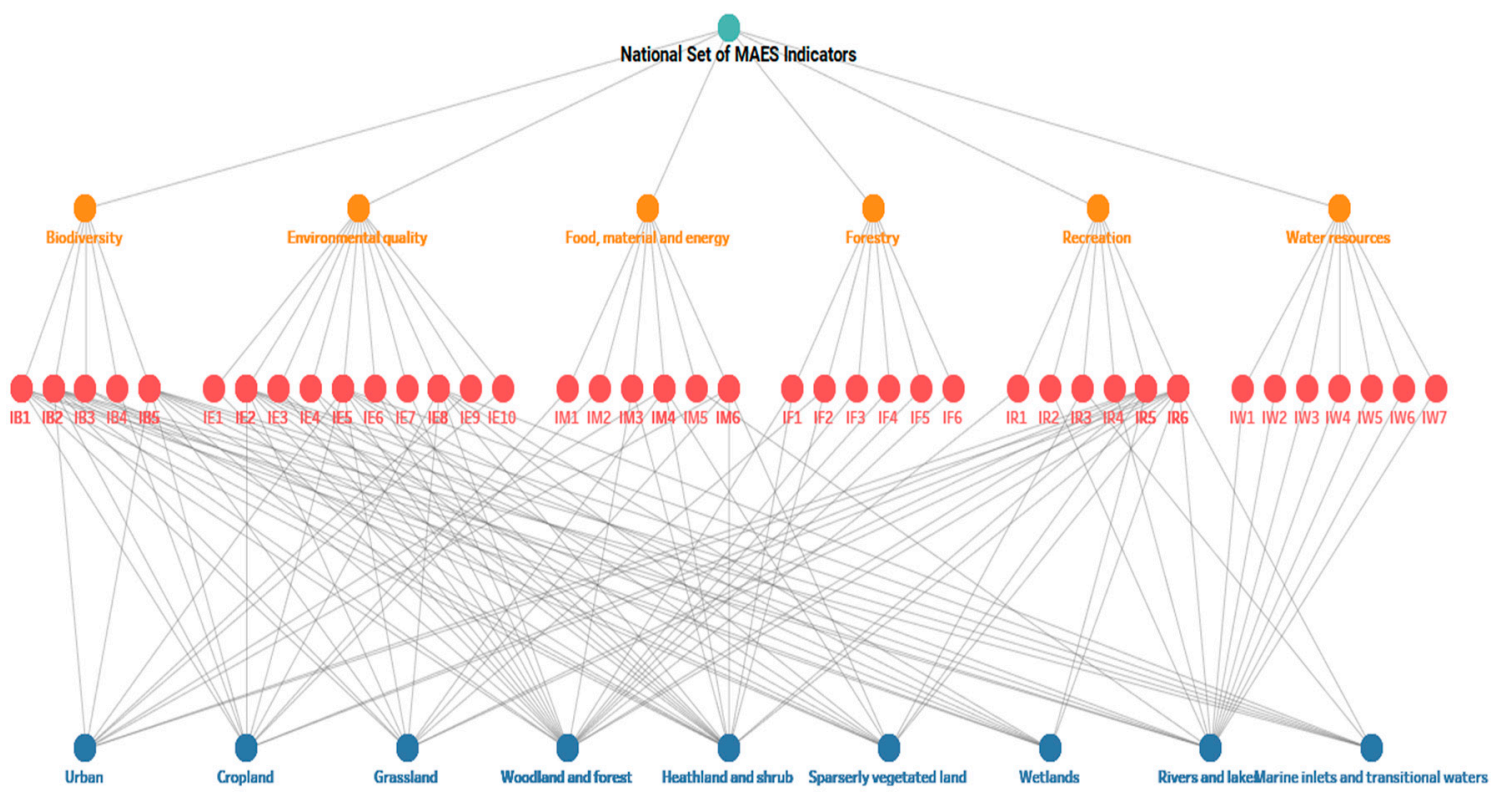

Figure 3. National set of indicators for Greece and their relationship with ecosystem types. IB: Biodiversity indicator, IE: Environmental quality indicator, IM: Food, material and energy indicator, IF: Forestry indicator, IR: Recreation indicator, IW: Water resources indicator (for a detailed abbreviations' reference, e.g., IB1, IB2, etc., see Table 3).

\subsubsection{Indicator Development and Implementation}

The drafted pre-defined protocols for the development and implementation of an indicator are presented in Supplementary Tables S2 and S3, respectively.

\subsection{Thematic Mapping}

\subsubsection{MAES-Related Dataset Availability and Potential ES Bundles and Hotspots}

\section{ES Bundles}

The thematic representation of co-existing MAES-related datasets, with spatial reference, at the $10 \times 10 \mathrm{~km}$ EEA reference grid-cell level (Figure 4), highlights that the available, ready-for-use information follows a terrain-, relief-oriented pattern, as follows: (i) cells of mountain ranges, especially in the northern Peloponnese and further north, contain information from five or more of the available datasets (yellow to red colors), an area accounting for 751 out of 2215 cells ( $34 \%$ of the total extent). This is due to a lack of typical (timber-oriented) forest management and subsequently, to a lack of the relevant datasets, at the mountainous, forest and woodland areas of north-central Peloponnese and further south. (ii) Plain areas are dominated by cultivated land (designated by the "cropland area" dataset), e.g., western Peloponnese and Thessaly, and represent main agricultural areas of the country (dominated by greenish cells), (iii) island areas (Ionian Islands, Crete and Aegean Islands) are also dominated by cells of four or less MAES-related datasets. The distribution of the cumulative presence of MAES-related data in the grid cells throughout Greece is given in Table 4. These results pinpoint serious data gaps, since only twelve datasets are available to be directly used for the national scale assessment. The most complete and detailed datasets are those for cropland and forestry. The detailed information at each cell is provided in Supplementary Table S4. 


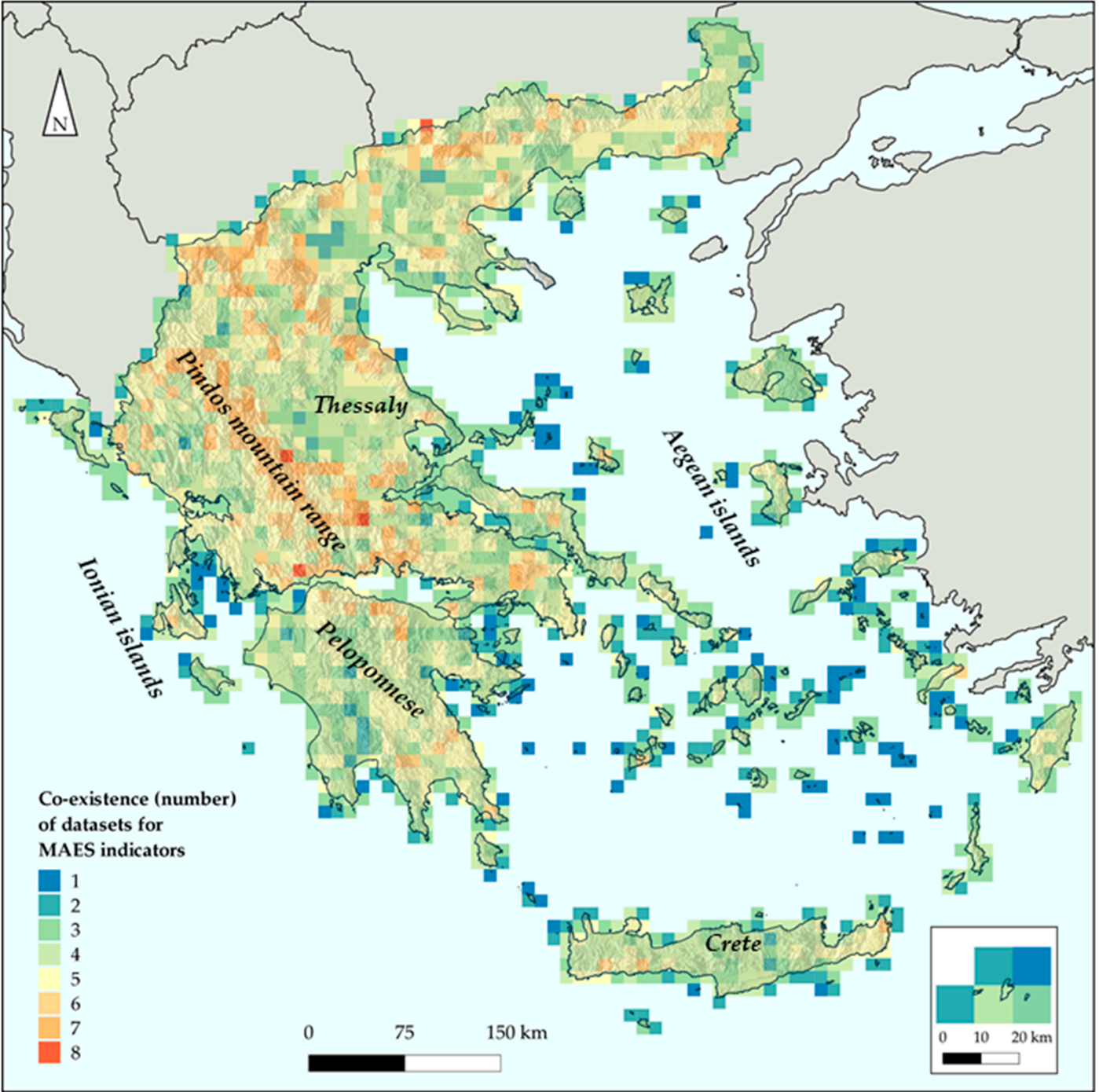

Figure 4. Ecosystem services bundles' map of Greece: a thematic representation of the co-existence of ES indicators at $10 \times 10 \mathrm{~km}$ EEA reference grid cell level. Indicators taken into account and rated: (i) forest management studies, (ii) wind energy stations, (iii) hydroelectric energy stations, (iv) solar energy stations, (v) national forests, (vi) Natura 2000 areas and/or wildlife refuges, (vii) "blue flag" beaches, (viii) thermal springs, (ix) inland waters boating and rafting, (x) mountain shelters, (xi) cropland area and (xii) water resources.

Table 4. Distribution of the cumulative presence of MAES-related data in the terrestrial $10 \times 10$ European Environment Agency (EEA) reference grid cells of Greece.

\begin{tabular}{ccc}
\hline Number of MAES-Related Datasets & Number of Corresponding Cells & \% of Total Cell Number \\
\hline 0 & 14 & 0.63 \\
1 & 98 & 4.42 \\
2 & 166 & 7.49 \\
3 & 474 & 21.41 \\
4 & 712 & 32.14 \\
5 & 482 & 21.76 \\
6 & 195 & 8.80 \\
7 & 69 & 3.12 \\
8 & 5 & 0.23 \\
\hline Total & $\mathbf{2 2 1 5}$ & $\mathbf{1 0 0}$ \\
\hline
\end{tabular}


ES bundling regions of Greece were also identified by analyzing the representativity of the various cell categories (i.e., cells rated from 0 to 6 , representing the utility of zero to six ecosystem indicator groups) in each of the 13 administrative regions of Greece (NUTS 2 level) (i.e., Attica, North Aegean, South Aegean, Crete, Eastern Macedonia and Thrace, Central Macedonia, Western Macedonia, Epirus, Thessaly, Ionian Islands, Western Greece, Central Greece and Peloponnese). By this, for each indicator group, readiness-data-gap maps have been drafted for the MAES implementation in Greece (Figure 5), as well as for their cumulative importance (Figure 6). These maps integrate each region's area as a parameter. In Figure 6, pie slices represent the percentage (\%) of EEA reference grid cells that include data for the application of zero, one, or more (numbers on the map) MAES indicator groups in each region of Greece. Pie size represents the relative percentage weighted by the NUTS 2 area size (i.e., number of $10 \times 10$ EEA reference grid cells included in the region). Grey tones also represent regions' area size (i.e., darker $=$ bigger, lighter $=$ smaller $)$.

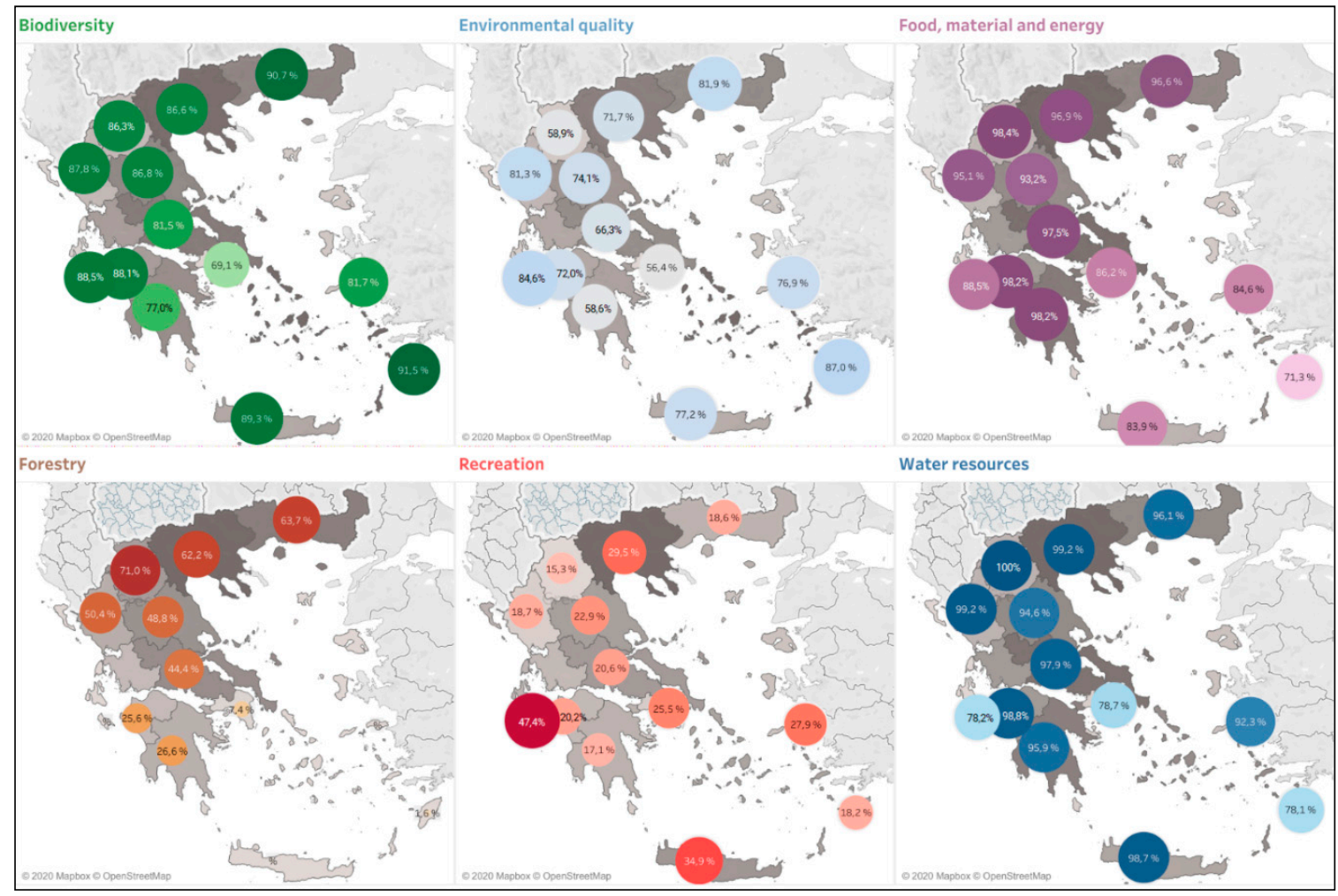

Figure 5. Readiness map for the MAES implementation in Greece, regarding the indicator groups of (i) Biodiversity, (ii) Environmental quality, (iii) Food material and Energy, (iv) Forestry, (v) Recreation and (vi) Water resources. Pie size represents the percentage (\%) of EEA reference grid cells that include data for the application of each indicator group in each region of Greece (NUTS 2). Greyscale shading per region refers to the number of cells in each region with data of each indicator group (darker shades represent regions with a higher total number of cells with relevant data). Data gaps for the particular indicators can be inferred from both percentage and relative shadedness. This combination provides a proxy of relative "readiness" for MAES studies. 


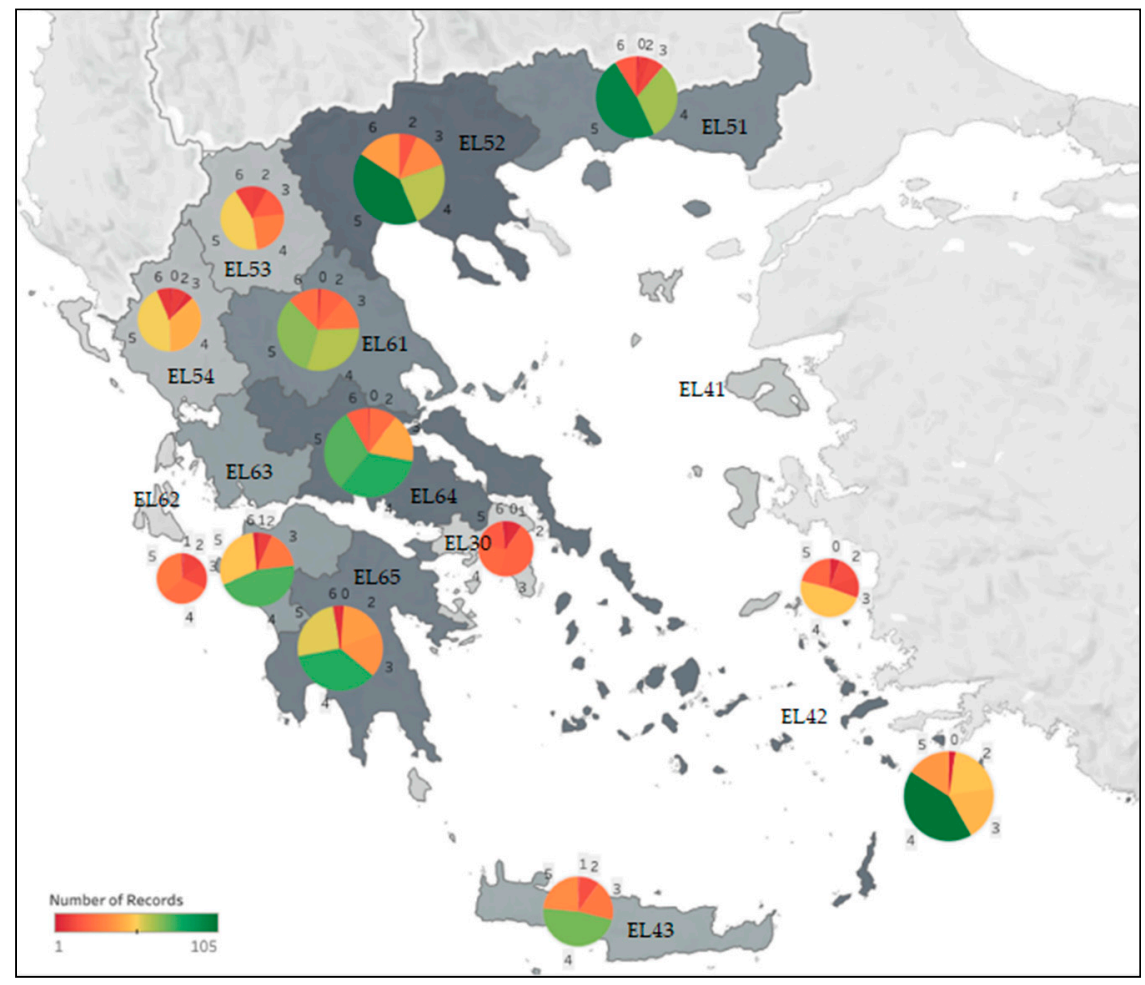

Figure 6. Readiness map for the MAES implementation in Greece. Pie slices represent the percentage of EEA reference grid cells that include data for the application of zero, one, or more MAES indicators (pie slice numbers) in each region of Greece (NUTS 2). Pie size represents the relative percentage weighted by NUTS 2 area size (i.e., number of $10 \times 10$ EEA reference grid cells included in the region). Grayscale shading represents the summation of the number of one or more indicator groups' data within the regions' grid cells. NUTS 2 Regions: Attica (EL30), North Aegean (EL41), South Aegean (EL42), Crete (EL43), Eastern Macedonia and Thrace (EL51), Central Macedonia (EL52), Western Macedonia (EL53), Epirus (EL54), Thessaly (EL61), Ionian Islands (EL62), Western Greece (EL63), Central Greece (EL64), Peloponnese (EL65).

The results of these maps suggest the following for the different indicator groups:

a. Biodiversity: most administrative regions are covered by an adequate number of biodiversity-related datasets (their majority is rated above 80\%). The regions of South Aegean, East Macedonia and Thrace and Crete are covered at highest rates $(91.5 \%, 90.7 \%$ and $89.3 \%$, respectively). The region of Attica, hosting the metropolitan center and capital of Greece-Athens, is in the last position of the classification, with $69.1 \%$ of its area covered by biodiversity-related datasets. Overall, area-size differentiations are not of significant importance.

b. Environmental quality: in most regions (nine out of thirteen), more than $70 \%$ of their surface is covered with data relevant to environmental quality. The region of Attica, including Athens, ranks in the last position of the list. Area-size differentiations are not of significant importance.

c. Food, material and energy: all regions are considered to have adequate spatial coverage regarding the available datasets for food, material and energy. Area-size differentiations are not of significant importance.

d. Forestry: regions of northern Greece, Western Macedonia, East Macedonia and Thrace and Central Macedonia are the first in the list with $71.0 \%, 63.7 \%$ and $62.2 \%$ cover of their surface, respectively. The Metropolitan region of Attica and island regions are placed last in the list: Attica 7.4\%, South Aegean 1.6\%, North Aegean and the Ionian Islands at $\%$. Area size is considered important and follows the pattern of area covered by the datasets. 
e. Recreation: most areas covered by recreation-related data are present in the Ionian Islands (47.4\%), Crete (34.9\%) and Central Macedonia (29.5\%). Regions' area size is important; for example, for the Ionian Islands region, it is highlighted that $47.4 \%$ of the area cover is of high importance regarding the relatively small area of the region.

f. Water resources: all regions are relatively well covered by water resources-related datasets and this is due mainly to the recent monitoring and assessment networks established for the EU Water Framework Directive. Although not apparent at this regional scale analysis, some local fine-scale data is still poorly compiled or surveyed, due to the country's high geographical fragmentation (many small river basins and small isolated wetlands). Area-size differentiations among regions are not of significant importance.

Central Macedonia, South Aegean and East Macedonia and Thrace are depicted (Figure 6) as the regions with larger areas, where, simultaneously, more than 4 indicators can be assessed. Regions of Central Greece, Peloponnese, Western Greece and Crete, follow. Epirus, North Aegean and Ionian Islands are depicted as of low importance in comparison with other regions, when considering areal extent (ha) for interpretation purposes. Area size is important for the interpretation of the results and highlights that larger area (e.g., Central Macedonia, Central Greece) is not a parameter linked to the available data diversity (e.g., Epirus, Ionian Islands, Attica).

\section{ES Hotspots}

Screening of the spatial distribution and density of the available datasets revealed areas which can be considered as ES hotspots. The following results were pinpointed for the three major ES categories (CICES sections):

a. Provisioning services: (i) 39\% of the terrestrial area is covered by agricultural areas, Thessaly, Western Greece, Central Macedonia, East Macedonia and Thrace and Crete can be considered as hotspots of agriculture-related provisioning services, (ii) approximately $15 \%$ of the country is under forest management control for timber and other forest products: Pindos, Rhodopi and Evros mountain ranges are considered as hotspots, (iii) most wind parks are developed in Central Greece, followed by Crete and East Macedonia and Thrace, and a local hotspot can be identified in Southern Evvoia (Central Greece), (iv) proposed and developed hydroelectric power plants from small dams hotspots are located throughout the mountain range of Pindos and continue southwards to the mountains of Northern Peloponnese: secondary hotspots are located lengthwise of north Greek borders, (v) a hotspot of solar energy production is identified at the surrounding area of Ptolemaida (Western Macedonia), while most solar energy units are developed in Thessaly and Central Greece.

b. Regulating and maintenance services: Most high-altitude mountains of Greece, wetland areas, lakes and numerous coastal areas can be perceived as hotspots for regulating and maintenance services. Although some regions are characterized by relative higher proportional area coverage by Natura 2000 sites and wildlife refuges than others (e.g., East Macedonia and Thrace versus Attica, respectively), the spatial distribution pattern of these hotspot areas designates them as of equal importance for every region.

c. Cultural services: Using the currently limited number of indicators the spatial pattern of the related information pinpoints Central Macedonia, Crete and the Ionian Islands as hotspot regions for cultural ecosystem services, hosting a dense concentration of high-quality mountain and coastal areas for recreational and spiritual activities/interactions (i.e., identified by a necessarily limited number of proxy indicators, being mountain shelters, "blue flag" beaches, thermal springs, fresh-water sports). This initial review shows that the restricted number of country-wide Cultural Ecosystem Services indicators should be increased and further developed.

Supplementary Figure S1 presents the thematic representation of the above-mentioned spatial distribution of ES-related datasets, for the hotspot identification. 
Relevance to Policies

The screening assessment to identify relevance among the adopted indicators and national and EU strategies and policies came up with the following results (Figures 7 and 8):

a. Biodiversity strategy: 21 relevant indicators, including 5 from Biodiversity, 8 from Environmental quality, 1 from Forestry, 4 from Recreation and 3 from Water resources groups.

b. Forest strategy: 25 relevant indicators, including 3 from Biodiversity, 7 from Environmental quality, 1 from Food, material and energy, 6 from Forestry, 4 from Recreation and 4 from Water resources groups.

c. Regional policy: 19 relevant indicators, including 7 from Environmental quality, 2 from Food, material and energy, 5 from Recreation and 5 from Water resources groups.

d. Agricultural policy: 21 relevant indicators, including 4 from Biodiversity, 4 from Environmental quality, 4 from Food, material and energy, 1 from Forestry, 1 from Recreation and 7 from Water resources groups.

e. Climate policy: 26 relevant indicators, including 2 from Biodiversity, 9 from Environmental quality, 4 from Food, material and energy, 4 from Forestry, 2 from Recreation and 5 from Water resources groups.

f. EU Green Deal: All (40) proposed indicators are relevant to the EU Green Deal policy. However, specific relevance is present among indicators and the thematic targets of the EU Green Deals.

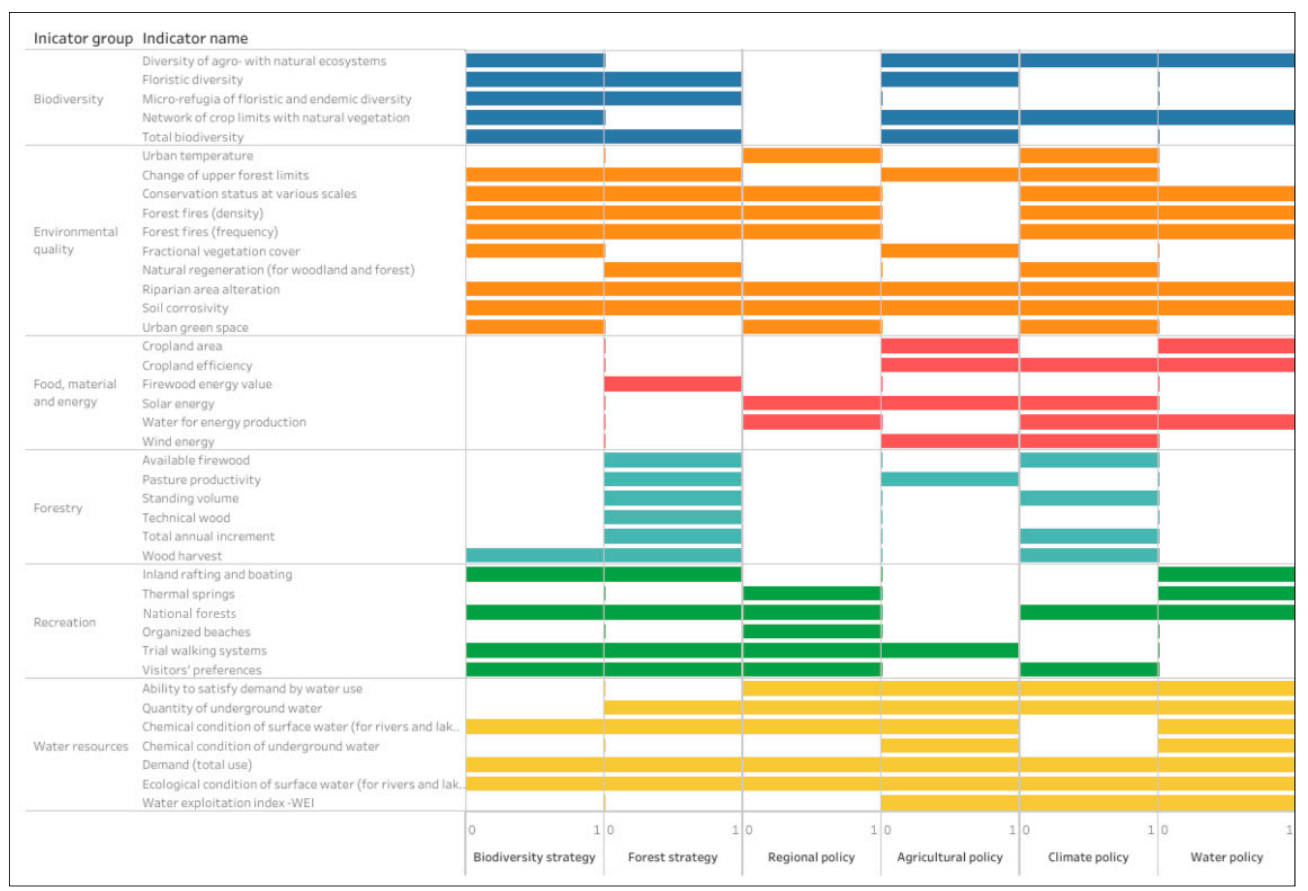

Figure 7. Correspondence matrix among indicators and national policies. 


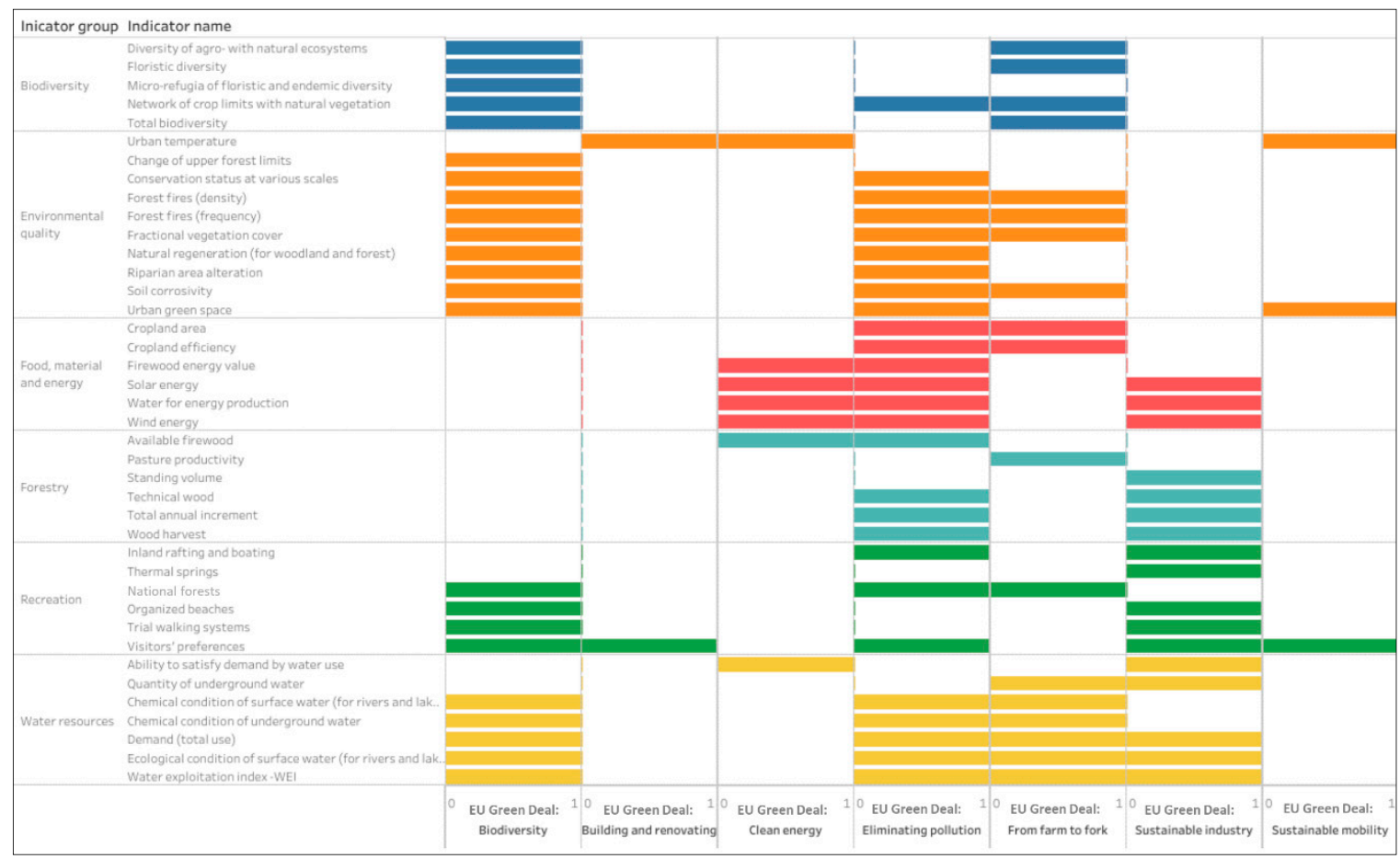

Figure 8. Correspondence matrix among indicators and the EU Green deal.

\section{Discussion}

Inventory, classification and standardized description of ES is the basis for any effort to measure, map or value them, and it is also the basis of being transparent regarding our methods and findings, so that we may effectively communicate and critique results [66]. However, the sheer number of ES and the correspondingly high number of indicators and large amounts of data needed for their assessment and valuation requires a pragmatic approach, such as the one proposed in the MAES indicators report, which focuses on using indicators supported by the available data [33]. At the same time, other criteria, such as validity and policy relevance, also need to be fulfilled regardless of data availability: ignore these and the usefulness of the indicators is seriously compromised [37,38,67,68]. Heink et al. [33] claim that (a) it is essential to show how indicators are related to goals and to conceptual frameworks and (b) the validity and relevance of indicators is just as important as data availability, as well as to the extent that the policy makers understand them.

The present study complies with the above-mentioned requirements and follows the CSLF (Credibility, Salience, Legitimacy, Feasibility) approach, which provides criteria for developing ecosystem service indicators [69]. Feasibility is of high importance in national ES assessments, since MS should (a) rapidly proceed with the baseline MAES status in their territory, (b) identify issues of importance regarding data gaps, management practices, trade-offs and/or sector policy conflicts and (c) move forward to detailed management-oriented and applied studies. Using available and feasible indicators and identifying data gaps avoids "paralysis by analysis" situations; taking such initiatives to apply indicators in practice also requires studying data gaps, risks, cultural idiosyncrasies and possible dysfunctions involved [70].

Our proposed MAES indicator framework does have some limitations since we are at the beginning of its state-wide development in Greece. Some of the available data are based on an uneven sampling distribution, and there are data-scarcity and data-consistency issues in many areas [34,41,71]; for example, higher quality information is available for some high-profile protected areas relative to the smaller and newer ones (e.g., Reference [72]), and this is broadly evident in our ecosystem bundles analysis (Figure 4). Moreover, work in the marine sector cannot at this time be fully integrated in this assessment framework since heterogeneity in data requirements, 
wide knowledge gaps and methodological limitations exist [34,73]. Although there are numerous challenges in applying policy-relevant ecosystems services with standardized methods in marine ecosystems, these problems are actively being explored [74-76]. Especially, in the Mediterranean MS, assessment approaches require careful considerations due to the diversity and intricacy of natural variability and cultural complexities [77]. A particular challenge among the ES types are Cultural Ecosystem Services, especially their streamlined assessment at the national and regional scales [78,79]. In our proposed MAES application, these are treated primarily within recreational values since it is difficult to survey other cultural services with any consistency on a state-wide scale (e.g., Reference [21]). CES are important in providing various methods to engage stakeholder and local applications (where conflict areas may also be identified) (e.g., References [80,81]). Obviously, we do not mean to degrade or denigrate other types of cultural ecosystem services [82,83], and important aspects such as landscape quality, including aesthetics and other landscape-scale attributes, are being actively investigated (e.g., References [84-86]). Many new methods and tools for landscape-scale analyses (e.g., References $[87,88]$ ) and approaches incorporating assessments of non-material benefits to societal well-being are being developed and new indicators should be incorporated in our adaptive national framework in the near future.

Despite some limitations, based on the results of the study, we consider that the available data in Greece are appropriate for national scale MAES studies (tier 3 and tier 2) and are sufficiently informative to support decision-making for many forms of natural resources management. Especially within the Natura 2000 sites (27.5\% of the terrestrial territory), data availability, administrative support and human resources are considered as of high capacity and the potential is high to prioritize the implementation of MAES studies within protected areas in the near future. In the frame of the LIFE-IP 4 Natura Project, detailed MAES studies will be implemented in selected sites, and the proposed indicators can be modified or altered to comply with local-level needs [89]. Also, due to a variety of recently applied policy-relevant monitoring programs promoted in Greece, such as water body ecological quality monitoring applications [90,91], the quality and quantity of perpetually updated data should rapidly increase. The drafted set of indicators and their spatial representation within an adaptive framework provide an adequate guide to support case-study sites' selection and future ameliorations of assessment accuracy and precision.

Moreover, it was considered important to develop a standardized reporting methodology to EU authorities based on the $10 \times 10 \mathrm{~km}$ EEA reference grid. Indicators' thematic maps on ES, data gaps and compliance with policy-related requirements produced in this study serve as an appropriate way of reporting the MS status on ES. Using the common ES coding provided by the CICES system, relevant maps at the EU level can be produced and in this way, we can identify ES bundles and hotspot areas across EU territory.

The next steps should be to conduct a nation-wide field assessment of ES and EC, using a web-based platform that has been developed by the University of Patras, for the LIFE-IP 4 NATURA project [92]. Plots within each EAA reference grid cell and for each ecosystem type are collected and this plots' dataset will: (a) support data validation and update, (b) thematic representation of ES actual and potential supply, based on field data (c) spatial trim literature ES supply and demand data and (d) assist the identification of ecosystems in degraded condition. This action, combined with the National Set of Indicators assessments, is expected to provide the best available knowledge for ecosystem types and their services in Greece and thus support decision- and policy-making with robust scientific information. Elaborated trade-off analysis is also needed and highlighted as a next step for the LIFE-IP 4 NATURA project, at least at the national scale. Fully developed trade-off analyses at this preliminary stage of MAES applications should proceed with extra care, since some types of ES, such as cultural services, may not be adequately represented by the current indicator set in all ecosystem types. However, displaying ES indicators makes trade-offs explicit and this may help facilitate management plans and project planning decisions; also, through stakeholder participation [28], this approach should promote sound value judgments at national and regional scales. 
To summarize, drafting and implementing a National Set of Indicators in each MS is crucial at the country, as well as at the EU level, and provides (complementary to MAES): (a) assistance for implementing other Actions of the EU Biodiversity Strategy, (b) guidance on how to use information on ecosystem services in impact assessments or for policies needs and (c) the existing link of biodiversity and ecosystem condition to ecosystem services and human well-being. However, this set of indicators is not a "passe-partout" for the MAES implementation, and modifications and alterations should be welcome, assessed and considered for use at different scales. In fact, and as stated by Costanza et al. [28], "there is not one right way to assess and value ecosystem services. There is, however, a wrong way, that is, not to do it at all". We consider this must be an adaptive process that should involve incremental steps towards evolution, amelioration and frequent review of the efficiency, consistency and usefulness of the first set of chosen indicators.

\section{Conclusions}

This study introduced the National Set of MAES indicators for Greece, a set of 40 indicators, aiming to support and promote ES and EC assessments throughout the Greek territory. The methodology complies with EU MAES frameworks and the ES classification system and through this, contributes to standardized ES reporting purposes at the MS level. This work is a synthesis of a multidisciplinary review of the available datasets in Greece, evaluated by experts representing national authorities, various university departments and research centers; thus, ensuring administrative validity and a broad scientific background. The results presented at the national and the regional level (NUTS 2 administrative regions) of Greece, highlight areas where: (a) MAES studies can be directly applied by implementing the proposed indicators and (b) MAES preparatory actions are needed (e.g., field surveys, data collection from non-digital/non-digitized sources, modelling) due to the explored data gaps. Finally, this set of indicators forms the official national basis on which future studies will be conducted for MAES reporting and implementation towards supporting the targets of the National and the EU Strategies and Policies.

Supplementary Materials: The following are available online at http://www.mdpi.com/1999-4907/11/5/595/s1: Figure S1: Thematic representation of the available, ES-related datasets, for the hotspot identification. Table S1: Correlations among the proposed national set of MAES indicators, ecosystem types, scale adequacy, tiers, EU Green Deal targets, National Strategies and Policies—-data sources are also provided. Table S2: Pre-defined indicator development protocol. Table S3: Pre-defined indicator implementation protocol. Table S4: Correlation matrix among EEA $10 \times 10$ reference grid cells, NUTS 2 regions, general group of indicators, EU Green Deal Targets, National Strategies and Policies.

Author Contributions: Conceptualization, I.P.K. and P.D.; methodology, I.P.K., G.M. and P.D.; software, I.P.K.; validation, I.P.K, E.S.B., G.M., V.V., S.Z. and P.D.; formal analysis, I.P.K., G.M., E.S.B., I.C. and P.D.; investigation, I.P.K., G.M., E.S.B., V.V., S.Z. and P.D.; resources, I.P.K., G.M., I.M. and P.D.; data curation, I.P.K., G.M., E.S.B., V.V. and I.C.; writing-original draft preparation, I.P.K., G.M., E.S.B., V.V. and P.D.; writing-review and editing, I.P.K., G.M., V.V., S.Z. and P.D.; visualization, I.P.K.; supervision, I.P.K. and P.D.; project administration, I.P.K. and P.D.; funding acquisition, I.M., G.M. and P.D. All authors have read and agreed to the published version of the manuscript.

Funding: This research was funded by the European Commission LIFE Integrated Project, LIFE-IP 4 NATURA "Integrated Actions for the Conservation and Management of Natura 2000 sites, species, habitats and ecosystems in Greece", Grant Number: LIFE 16 IPE/GR/000002.

Acknowledgments: The study was conducted within the framework of the National Mapping and Assessment of Ecosystem and their Services project, under the LIFE-IP 4 NATURA project. We would like to thank the Hellenic Ministry of the Environment and Energy and the Hellenic Ministry of Rural Development and Food, for the provision of nation-wide datasets for forestry, agriculture and mapping material. We also thank Constantia Patelodimou for all the assistance in this work, especially on database handling and visualizations under the Tableau online platform.

Conflicts of Interest: The authors declare no conflict of interest. The funder had no role in the design of the study; in the collection, analyses, or interpretation of data; in the writing of the manuscript, or in the decision to publish the results. 


\section{References}

1. European Commission. Our Life Insurance, Our Natural Capital: An EU Biodiversity Strategy to Communication from the Commission to the European Parliament, the Council the Economic and Social Committee and the Committee of the Regions; Directorate-General for Environment: Brussels, Belgium, 2011.

2. Maes, J.; Teller, A.; Erhard, M.; Liquete, C.; Braat, L.; Berry, P.; Egoh, B.; Puydarrieus, P.; Fiorina, C.; Santos, F.; et al. Mapping and Assessment of Ecosystem and Their Services. An Analytical Framework for Ecosystem Assessments under Action 5 of the EU Biodiversity Strategy to 2020; Publications Office of the European Union: Luxemburg, 2013; ISBN 9789279293696.

3. Haines-Young, R.; Paterson, J.; Potschin, M.; Wilson, A.; Kass, G. The UK NEA Scenarios: Development of Storylines and Analysis of Outcomes; The UK National Ecosystem Assessment Technical Report; United Nations Environment Programme World Conservation Monitoring Centre (UNEP-WCMC): Cambridge, UK, 2011.

4. Spanish National Ecosystem Assessment. Ecosystems and Biodiversity for Human Wellbeing: Synthesis of Key Findings; Ministerio de Agricultura, Alimentación y Medio Ambiente: Madrid, Spain, 2014.

5. Bratanova-Doncheva, S.; Chipev, N.; Gocheva, K.; Stoyan, V.; Fikova, R. Methodological framework for assessment and mapping of ecosystem condition and ecosystem services in Bulgaria. In Conceptual Bases and Principles of Application; Digital Illusions: Clorindm, Argentina, 2017; ISBN 978-619-7379-21-1.

6. Grunewald, K.; Herold, H.; Marzelli, S.; Meinel, G.; Richter, B.; Syrbe, R.-U.; Walz, U. Assessment of ecosystem services at the national level in Germany-Illustration of the concept and the development of indicators by way of the example wood provision. Ecol. Indic. 2016, 70, 181-195. [CrossRef]

7. Grunewald, K.; Syrbe, R.U.; Walz, U.; Richter, B.; Meinel, G.; Herold, H.; Marzelli, S. Germany's Ecosystem Services-State of the Indicator Development for a Nationwide Assessment and Monitoring. One Ecosyst. 2017, 2, e14021. [CrossRef]

8. Henke, J.M.; Petropoulos, G.P. A GIS-based exploration of the relationships between human health, social deprivation and ecosystem services: The case of Wales, UK. Appl. Geogr. 2013, 45, 77-88. [CrossRef]

9. Palomo, I.; Martín-López, B.; Zorrilla-Miras, P.; Del Amo, D.G.; Montes, C. Deliberative mapping of ecosystem services within and around Doñana National Park (SW Spain) in relation to land use change. Reg. Environ. Chang. 2013, 14, 237-251. [CrossRef]

10. Cortinovis, C.; Geneletti, D. Ecosystem services in urban plans: What is there, and what is still needed for better decisions. Land Use Policy 2018, 70, 298-312. [CrossRef]

11. Burkhard, B.; Maes, J.; Potschin-Young, M.; Santos-Martín, F.; Geneletti, D.; Stoev, P.; Kopperoinen, L.; Adamescu, C.; Esmail, B.A.; Arany, I.; et al. Mapping and assessing ecosystem services in the EU-Lessons learned from the ESMERALDA approach of integration. One Ecosyst. 2018, 3, e29153. [CrossRef]

12. Burkhard, B.; Sapundzhieva, A.; Kuzmova, I.; Maes, J.; Geneletti, D.; Adem Esmail, B.; Potschin-Young, M.; Santos-Martin, F.; Mulders, S.; Kopperoinen, L.; et al. Action 5 Implementation Plan. Deliverable D1.7 EU Horizon 2020 ESMERALDA Project; Grant agreement No. 642007; Leipzig University: Hannover, Germany, 2018.

13. Burkhard, B.; Maes, J. (Eds.) Mapping Ecosystem Services; Pensoft Publishers: Sofia, Bulgaria, 2017.

14. ESMERALDA MAES Explorer. Available online: http://www.maes-explorer.eu (accessed on 12 April 2020).

15. Santos-Martin, F.; Viinikka, A.; Mononen, L.; Brander, L.; Vihervaara, P.; Liekens, I.; Potschin-Young, M. Creating an operational database for Ecosystems Services Mapping and Assessment Methods. One Ecosyst. 2018, 3, e26719. [CrossRef]

16. Burkhard, B.; Santos-Martín, F.; Nedkov, S.; Maes, J. An operational framework for integrated Mapping and Assessment of Ecosystems and their Services (MAES). One Ecosyst. 2018, 3, e22831. [CrossRef]

17. Grêt-Regamey, A.; Weibel, B.; Kienast, F.; Rabe, S.-E.; Zulian, G. A tiered approach for mapping ecosystem services. Ecosyst. Serv. 2015, 13, 16-27. [CrossRef]

18. Albert, C.; Bonn, A.; Burkhard, B.; Daube, S.; Dietrich, K.; Engels, B.; Frommer, J.; Götzl, M.; Grêt-Regamey, A.; Job-Hoben, B.; et al. Towards a national set of ecosystem service indicators: Insights from Germany. Ecol. Indic. 2016, 61, 38-48. [CrossRef]

19. Maes, J.; Egoh, B.; Willemen, L.; Liquete, C.; Vihervaara, P.; Schägner, J.P.; Grizzetti, B.; Drakou, E.; La Notte, A.; Zulian, G.; et al. Mapping ecosystem services for policy support and decision making in the European Union. Ecosyst. Serv. 2012, 1, 31-39. [CrossRef] 
20. Mononen, L.; Auvinen, A.-P.; Ahokumpu, A.-L.; Rönkä, M.; Aarras, N.; Tolvanen, H.; Kamppinen, M.; Viirret, E.; Kumpula, T.; Vihervaara, P. National ecosystem service indicators: Measures of social-ecological sustainability. Ecol. Indic. 2016, 61, 27-37. [CrossRef]

21. Tratalos, J.; Haines-Young, R.; Potschin, M.; Fish, R.; Church, A. Cultural ecosystem services in the UK: Lessons on designing indicators to inform management and policy. Ecol. Indic. 2016, 61, 63-73. [CrossRef]

22. Albert, C.; Hauck, J.; Buhr, N.; Von Haaren, C. What ecosystem services information do users want? Investigating interests and requirements among landscape and regional planners in Germany. Landsc. Ecol. 2014, 29, 1301-1313. [CrossRef]

23. Albert, C.; Galler, C.; Hermes, J.; Neuendorf, F.; Von Haaren, C.; Lovett, A. Applying ecosystem services indicators in landscape planning and management: The ES-in-Planning framework. Ecol. Indic. 2016, 61, 100-113. [CrossRef]

24. Hauck, J.; Schweppe-Kraft, B.; Albert, C.; Görg, C.; Jensen, R.; Fürst, C.; Maes, J.; Ring, I.; Hönigová, I.; Burkhard, B.; et al. The Promise of the Ecosystem Services Concept for Planning and Decision-Making. GAIA Ecol. Perspect. Sci. Soc. 2013, 22, 232-236. [CrossRef]

25. Hayek, U.W.; Teich, M.; Klein, T.; Grêt-Regamey, A. Bringing ecosystem services indicators into spatial planning practice: Lessons from collaborative development of a web-based visualization platform. Ecol. Indic. 2016, 61, 90-99. [CrossRef]

26. Chee, Y.E. An ecological perspective on the valuation of ecosystem services. Biol. Conserv. 2004, 120, 549-565. [CrossRef]

27. McCauley, D.J. Selling out on nature. Nature 2006, 443, 27-28. [CrossRef]

28. Costanza, R.; De Groot, R.; Braat, L.; Kubiszewski, I.; Kubiszewski, I.; Sutton, P.; Farber, S.; Grasso, M. Twenty years of ecosystem services: How far have we come and how far do we still need to go? Ecosyst. Serv. 2017, 28, 1-16. [CrossRef]

29. Russell-Smith, J.; Lindenmayer, D.; Kubiszewski, I.; Green, P.; Costanza, R.; Campbell, A. Moving beyond evidence-free environmental policy. Front. Ecol. Environ. 2015, 13, 441-448. [CrossRef]

30. DeGroot, R.; Fisher, B.; Christie, M.; Aronson, J.; Braat, L.; Gowdy, J.; Haines-Young, R.; Maltby, E.; Neuville, A.; Polasky, S.; et al. Integrating the ecological and economic dimensions in biodiversity and ecosystem service valuation. In The Economics of Ecosystems and Biodiversity: Ecological and Economic Foundations; Earthscan: London, UK; Washington, DC, USA, 2012; ISBN 9781849775489.

31. Braat, L.C.; De Groot, R. The ecosystem services agenda: bridging the worlds of natural science and economics, conservation and development, and public and private policy. Ecosyst. Serv. 2012, 1, 4-15. [CrossRef]

32. Maes, J.; Teller, A.; Erhard, M.; Liquete, C.; Braat, L.; Berry, P.; Egoh, B.; Puydarrieux, P.; Fiorina, C.; Santos, F. Mapping and Assessment of Ecosystems and Their Services. Indicators for Ecosystem Assessments under Action 5 of the EU Biodiversity Strategy to 2020; Publications office of the European Union: Luxemburg, 2014; ISBN 9789279361616.

33. Heink, U.; Hauck, J.; Jax, K.; Sukopp, U. Requirements for the selection of ecosystem service indicators - The case of MAES indicators. Ecol. Indic. 2016, 61, 18-26. [CrossRef]

34. Dimopoulos, P.; Drakou, E.; Kokkoris, I.; Katsanevakis, S.; Kallimanis, A.; Tsiafouli, M.; Bormpoudakis, D.; Kormas, K.; Arends, J. The need for the implementation of an Ecosystem Services assessment in Greece: Drafting the national agenda. One Ecosyst. 2017, 2, e13714. [CrossRef]

35. Smart, J.J.C.; Hempel, C.G. Foundations of the Unity of Science. Volume II, no. 7: Fundamentals of Concept Formation in Empirical Science. Philos. Rev. 1953, 62, 473. [CrossRef]

36. Williams, D.G.; Babbie, E.R. The Practice of Social Research. Contemp. Sociol. A J. Rev. 1976, 5, 163. [CrossRef]

37. Heink, U.; Kowarik, I. What criteria should be used to select biodiversity indicators? Biodivers. Conserv. 2010, 19, 3769-3797. [CrossRef]

38. Maes, J.; Teller, A.; Erhard, M.; Grizzetti, B.; Barredo, J.I.; Paracchini, M.L.; Condé, S.; Somma, F.; Orgiazzi, A.; Jones, A.; et al. Mapping and Assessment of Ecosystems and their Services: An Analytical Framework for Ecosystem Condition; Publications office of the European Union: Luxemburg, 2018; ISBN 978-92-79-74288-0.

39. Kokkoris, I.P.; Bekri, E.S.; Skuras, D.; Vlami, V.; Zogaris, S.; Maroulis, G.; Dimopoulos, D.; Dimopoulos, P. Integrating MAES implementation into protected area management under climate change: A fine-scale application in Greece. Sci. Total. Environ. 2019, 695, 133530. [CrossRef] 
40. Hatziiordanou, L.; Fitoka, E.; Hadjicharalampous, E.; Votsi, N.; Palaskas, D.; Malak, D. Indicators for mapping and assessment of ecosystem condition and of the ecosystem service habitat maintenance in support of the EU Biodiversity Strategy to 2020. One Ecosyst. 2019, 4, e32704. [CrossRef]

41. Vlami, V.; Kokkoris, I.P.; Zogaris, S.; Cartalis, C.; Kehayias, G.; Dimopoulos, P. Cultural landscapes and attributes of "culturalness" in protected areas: An exploratory assessment in Greece. Sci. Total. Environ. 2017, 595, 229-243. [CrossRef]

42. Kokkoris, I.P.; Drakou, E.; Maes, J.; Dimopoulos, P. Ecosystem services supply in protected mountains of Greece: Setting the baseline for conservation management. Int. J. Biodivers. Sci. Ecosyst. Serv. Manag. 2017, 14, 45-59. [CrossRef]

43. Kokkoris, I.; Dimopoulos, P.; Xystrakis, F.; Tsiripidis, I. National scale ecosystem condition assessment with emphasis on forest types in Greece. One Ecosyst. 2018, 3, e25434. [CrossRef]

44. Nikolaidou, C.; Votsi, N.-E.; Sgardelis, S.; Halley, J.; Pantis, J.; Tsiafouli, M. Ecosystem Service capacity is higher in areas of multiple designation types. One Ecosyst. 2017, 2, e13718. [CrossRef]

45. Hellenic Ecosystem Services Partnership (HESP). Available online: https://www.es-partnership.org/ community/regional-chapters/south-east-europe/greece-hesp/ (accessed on 12 April 2020).

46. LIFE-IP 4 NATURA. Available online: https://edozoume.gr/en/ (accessed on 12 April 2020).

47. United Nations. European Commission; Food and Agricultural Organization of the United Nations; Organization for Economic Co-operation and Development. In World Bank System of Environmental-Economic Accounting 2012: Experimental Ecosystem Accounting; United Nations: New York, NY, USA, 2014; ISBN 9789210559263.

48. Ecosystem Types of Europe. Available online: https://www.eea.europa.eu/data-and-maps/data/ecosystemtypes-of-europe-1 (accessed on 12 April 2020).

49. CORINE Land Cover. Available online: https://land.copernicus.eu/pan-european/corine-land-cover (accessed on 12 April 2020).

50. Interpretation Manual of European Union Habitats-EUR28; European Commission, DG Environment: Brussels, Belgium, 2013; ISBN HAB 96/2 FINAL_EN Version EUR 15.

51. Dimopoulos, P.; Bergmeier, E.; Theodoropoulos, K.; Fischer, P.; Tsiafouli, M. Monitoring Guide for Habitat types and Plant Taxa in Natura 2000 Sites with Management Bodies; University of Ioannina, Ministry of the Environment: Agrinio, Greece, 2005; ISBN 960-233-168-2.

52. Development of Large Scale (1:5000) Spatial Data Infrastructure for Terrestrial Areas Protected under the «Natura 2000» Network at a National Scale 2016. Available online: http://www.ypeka.gr/LinkClick.aspx? fileticket=txXACYhOLPI\%3d\&tabid=37\&language=el-GR (accessed on 10 April 2018).

53. Linkages of Species and Habitat Types to MAES Ecosystems. Available online: https://www.eea.europa.eu/ data-and-maps/data/linkages-of-species-and-habitat\#tab-metadata (accessed on 12 April 2020).

54. The European Green Deal. Communication from the Commission to the European Parliament, the European Council, the Council, the European Economic and Social Committee and the Committee of the Regions. Brussels. 2019. Available online: https:/ec.europa.eu/info/sites/info/files/european-green-dealcommunication_en.pdf (accessed on 12 April 2020).

55. National Biodiversity Strategy and Action Plan; Hellenic Ministry of Environment and Climate Change: Athens, Greece, 2014; ISBN 978-960-7284-33-4.

56. Smith, A.; Harrison, P.; Soba, M.P.; Archaux, F.; Blicharska, M.; Egoh, B.; Erős, T.; Domenech, N.F.; György, Á.I.; Haines-Young, R.; et al. How natural capital delivers ecosystem services: A typology derived from a systematic review. Ecosyst. Serv. 2017, 26, 111-126. [CrossRef]

57. Pouso, S.; Uyarra, M.C.; Borja, A. Recreational fishers' perceptions and behaviour towards cultural ecosystem services in response to the Nerbioi estuary ecosystem restoration. Estuarine, Coast. Shelf Sci. 2018, 208, 96-106. [CrossRef]

58. Grizzetti, B.; Liquete, C.; Pistocchi, A.; Vigiak, O.; Zulian, G.; Bouraoui, F.; De Roo, A.; Cardoso, A. Relationship between ecological condition and ecosystem services in European rivers, lakes and coastal waters. Sci. Total. Environ. 2019, 671, 452-465. [CrossRef]

59. Haines-Young, R.; Potschin, M. CICES Towards a Common Classification of Ecosystem Services. Available online: https://cices.eu/ (accessed on 12 April 2020). 
60. Kettunen, M.; Ministers, N.C.O.; Vihervaara, P.; Kinnunen, S.; D’Amato, D.; Badura, T.; Argimon, M.; Brink, P.T. Socio-economic importance of ecosystem services in the Nordic Countries. In Socio-Economic Importance of Ecosystem Services in the Nordic Countries; Nordic Council of Ministers: Copenhagen, Denmark, 2012.

61. Ferrari, M.; Geneletti, D. Mapping and assessing multiple ecosystem services in an alpine region: A study in Trentino, Italy. Ann. Bot. 2014, 4, 65-71.

62. Nedkov, S.; Borisova, B.; Koulov, B.; Zhiyanski, M.; Bratanova-Doncheva, S.; Nikolova, M.; Kroumova, J. Towards integrated mapping and assessment of ecosystems and their services in Bulgaria: The Central Balkan case study. One Ecosyst. 2018, 3, e25428. [CrossRef]

63. EEA Reference Grid. Available online: https://www.eea.europa.eu/data-and-maps/data/eea-reference-grids-2 (accessed on 12 April 2020).

64. Tableau Online 2020.1. Available online: https://www.tableau.com/products/cloud-bi (accessed on 12 April 2020).

65. Egoh, B.; Reyers, B.; Rouget, M.; Richardson, D.M.; Le Maitre, D.C.; Van Jaarsveld, A.S. Mapping ecosystem services for planning and management. Agric. Ecosyst. Environ. 2008, 127, 135-140. [CrossRef]

66. Czúcz, B.; Arany, I.; Potschin-Young, M.; Bereczki, K.; Kertész, M.; Kiss, M.; Aszalós, R.; Haines-Young, R. Where concepts meet the real world: A systematic review of ecosystem service indicators and their classification using CICES. Ecosyst. Serv. 2018, 29, 145-157. [CrossRef]

67. Feld, C.; Sousa, J.P.; Da Silva, P.M.; Dawson, T. Indicators for biodiversity and ecosystem services: Towards an improved framework for ecosystems assessment. Biodivers. Conserv. 2010, 19, 2895-2919. [CrossRef]

68. Müller, F.; Burkhard, B. The indicator side of ecosystem services. Ecosyst. Serv. 2012, 1, 26-30. [CrossRef]

69. Van Oudenhoven, A.P.E.; Schröter, M.; Drakou, E.; Geijzendorffer, I.R.; Jacobs, S.; Van Bodegom, P.; Chazee, L.; Czúcz, B.; Grunewald, K.; Lillebø, A.; et al. Key criteria for developing ecosystem service indicators to inform decision making. Ecol. Indic. 2018, 95, 417-426. [CrossRef]

70. Van Reeth, W. Ecosystem Service Indicators in Flanders: Are We Measuring What We Want to Manage? Instituut voor Natuuren Bosonderzoek: Brussel, Belgium, 2014.

71. Zogaris, S.; Economou, A.N. The biogeographic characteristics of the river basins of Greece. In The Rivers of Greece: Evolution, Current Status and Perspectives; Skoulikidis, N., Karaouzas, I., Dimitriou, E., Eds.; Springer-Verlag: Berlin/Heidelberg Germany, 2017; pp. 53-95.

72. Tsianou, M.A.; Mazaris, A.D.; Kallimanis, A.S.; Deligioridi, P.-S.K.; Apostolopoulou, E.; Pantis, J.D. Identifying the criteria underlying the political decision for the prioritization of the Greek Natura 2000 conservation network. Biol. Conserv. 2013, 166, 103-110. [CrossRef]

73. Katsanevakis, S.; Sini, M.; Dailianis, T.; Gerovasileiou, V.; Koukourouvli, N.; Topouzelis, K.; Ragkousis, M. Identifying where vulnerable species occur in a data-poor context: Combining satellite imaging and underwater occupancy surveys. Mar. Ecol. Prog. Ser. 2017, 577, 17-32. [CrossRef]

74. Börger, T.; Beaumont, N.J.; Pendleton, L.; Boyle, K.J.; Cooper, P.; Fletcher, S.; Haab, T.; Hanemann, M.; Hooper, T.L.; Hussain, S.S.; et al. Incorporating ecosystem services in marine planning: The role of valuation. Mar. Policy 2014, 46, 161-170. [CrossRef]

75. Rodrigues, J.G.; Conides, A.; Rodriguez, S.R.; Raicevich, S.; Pita, P.; Kleisner, K.; Pita, C.; Lopes, P.; Roldán, V.A.; Ramos, S.; et al. Marine and Coastal Cultural Ecosystem Services: Knowledge gaps and research priorities. One Ecosyst. 2017, 2. [CrossRef]

76. Salomidi, M.; Katsanevakis, S.; Borja, A.; Braeckman, U.; Damalas, D.; Galparsoro, I.; Mifsud, R.; Mirto, S.; Pascual, M.; Pipitone, C.; et al. Assessment of goods and services, vulnerability, and conservation status of European seabed biotopes: A stepping stone towards ecosystem-based marine spatial management. Mediterr. Mar. Sci. 2012, 13, 49-88. [CrossRef]

77. Balzan, M.V.; Pinheiro, A.M.; Mascarenhas, A.; Morán-Ordóñez, A.; Ruiz-Frau, A.; Carvalho-Santos, C.; Vogiatzakis, I.; Arends, J.; Santana-Garcon, J.; Roces-Díaz, J.V.; et al. Improving ecosystem assessments in Mediterranean social-ecological systems: A DPSIR analysis. Ecosyst. People 2019, 15, 136-155. [CrossRef]

78. Satz, D.; Gould, R.K.; Chan, K.M.A.; Guerry, A.; Norton, B.; Satterfield, T.; Halpern, B.S.; Levine, J.; Woodside, U.; Hannahs, N.; et al. The Challenges of Incorporating Cultural Ecosystem Services into Environmental Assessment. Ambio 2013, 42, 675-684. [CrossRef]

79. Jaligot, R.; Hasler, S.; Chenal, J. National assessment of cultural ecosystem services: Participatory mapping in Switzerland. Ambio 2019, 48, 1219-1233. [CrossRef] [PubMed]

80. Raum, S. A framework for integrating systematic stakeholder analysis in ecosystem services research: Stakeholder mapping for forest ecosystem services in the UK. Ecosyst. Serv. 2018, 29, 170-184. [CrossRef] 
81. Vlami, V.; Danek, J.; Zogaris, S.; Gallou, E.; Kokkoris, I.P.; Kehayias, G.; Dimopoulos, P. Residents' Views on Landscape and Ecosystem Services during a Wind Farm Proposal in an Island Protected Area. Sustainability 2020, 12, 2442. [CrossRef]

82. Tengberg, A.; Fredholm, S.; Eliasson, I.; Knez, I.; Saltzman, K.; Wetterberg, O. Cultural ecosystem services provided by landscapes: Assessment of heritage values and identity. Ecosyst. Serv. 2012, 2, 14-26. [CrossRef]

83. Schaubroeck, T. The Concept of Cultural Ecosystem Services Should Not Be Abandoned. BioScienece 2019, 69, 585. [CrossRef]

84. Schaich, H.; Bieling, C.; Plieninger, T. Linking Ecosystem Services with Cultural Landscape Research. GAIA Ecol. Perspect. Sci. Soc. 2010, 19, 269-277. [CrossRef]

85. Ungaro, F.; Hafner, K.; Zasada, I.; Piorr, A. Mapping cultural ecosystem services: Connecting visual landscape quality to cost estimations for enhanced services provision. Land Use Policy 2016, 54, 399-412. [CrossRef]

86. Vlami, V.; Zogaris, S.; Djuma, H.; Kokkoris, I.P.; Kehayias, G.; Dimopoulos, P. A Field Method for Landscape Conservation Surveying: The Landscape Assessment Protocol (LAP). Sustainability 2019, 11, 2019. [CrossRef]

87. Lorilla, R.S.; Kalogirou, S.; Poirazidis, K.; Kefalas, G. Identifying spatial mismatches between the supply and demand of ecosystem services to achieve a sustainable management regime in the Ionian Islands (Western Greece). Land Use Policy 2019, 88, 104171. [CrossRef]

88. Lorilla, R.S.; Poirazidis, K.; Detsis, V.; Kalogirou, S.; Chalkias, C. Socio-ecological determinants of multiple ecosystem services on the Mediterranean landscapes of the Ionian Islands (Greece). Ecol. Model. 2020, 422, 108994. [CrossRef]

89. LIFE IP 4Natura - Integrated Actions for the Conservation and Management of Natura 2000 Sites, Species, Habitats and Ecosystems in Greece (LIFE16 IPE/GR/000002). Available online: https://ec.europa.eu/environment/life/project/ Projects/index.cfm?fuseaction=search.dspPage\&n_proj_id=6520 (accessed on 12 April 2020).

90. Economou, A.N.; Zogaris, S.; Vardakas, L.; Koutsikos, N.; Chatzinikolaou, Y.; Kommatas, D.; Kapakos, Y.; Giakoumi, S.; Oikonomou, E.; Tachos, V. Developing policy-relevant river fish monitoring in Greece: Insights from a nation-wide survey. Mediterr. Mar. Sci. 2016, 17, 302. [CrossRef]

91. Mentzafou, A.; Panagopoulos, Y.; Dimitriou, E. Designing the National Network for Automatic Monitoring of Water Quality Parameters in Greece. Water 2019, 11, 1310. [CrossRef]

92. MAES GR Tool: Mapping and Assessment of Ecosystems and their Services: A Dynamic Tool for Ecosystem Services. Available online: https://83.212.170.27:8085/login (accessed on 12 April 2020). 